\title{
Recent Rainfall Variability Over a Dryland Ecosystem of North Western India
}

\section{DIVYA SAINI}

Kurukshetra University

PANKAJ BHARDWAJ

Kurukshetra University

Omvir Singh ( $\square$ ovshome@yahoo.com )

Kurukshetra University https://orcid.org/0000-0003-3594-4215

\section{Research Article}

Keywords: Rainfall, heavy rainfall events, trend analysis, dryland ecosystem, India

Posted Date: July 6th, 2021

DOI: https://doi.org/10.21203/rs.3.rs-378598/v1

License: (a) This work is licensed under a Creative Commons Attribution 4.0 International License. Read Full License 


\section{Abstract}

In this study, an attempt has been made to examine the recent rainfall variability by means of daily rainfall data of 33 well spread stations over dryland ecosystem of Rajasthan in north western India during 1961-2017. For trend analysis, Mann-Kendall, Sen's slope estimator and simple linear regression test have been used (at 95\% confidence level). The results have shown a high interannual variability in rainfall occurrence varying from $277 \mathrm{~mm}$ (in year 2002) to $839 \mathrm{~mm}$ (in year 1975) with mean of $583 \mathrm{~mm}$ over this dryland ecosystem. Most of the rainfall deficit years have occurred with El-Nino years. The mean annual rainfall has shown a marginal non-significant upward trend over the ecosystem. The station-wise mean annual rainfall has revealed a significant rising trend over Barmer, Churu, Ganganagar, Jaisalmer and Pratapgarh stations. Interestingly, three year running average has shown a cyclic pattern of rainfall over dryland ecosystem under the changing climatic conditions. The spatial pattern has exhibited that the mean annual rainfall decreases from east and south east (more than 850 mm) to west and north west (less than $400 \mathrm{~mm}$ ), which is mainly associated with the presence of Aravalli Mountains spreading north east to south west in central Rajasthan. Remarkably, majority of stations positioned in western parts of dryland ecosystem have shown increasing rainfall trends, whereas some stations located in eastern parts have recorded a non-significant declining trend. The magnitude of significant rising trend has varied from $5.34 \mathrm{~mm} / \mathrm{year}$ (Pratapgarh station) to $2.17 \mathrm{~mm}$ /year (Jaisalmer station). Also, the frequency of heavy rainfall events has shown a positive trend with significant increasing trends over Bharatpur, Jaisalmer and Pratapgarh stations, whereas Bundi station has shown significant decreasing trend.

\section{Introduction}

Rainfall and temperature are vital climatic parameters, which have been frequently used to identify the alterations in global climatic conditions (Mayowa et al. 2015; Sa'adi et al. 2019). Global ocean's and land surface temperature trend has revealed a warming of $0.85^{\circ} \mathrm{C}$ (ranging between $0.65^{\circ}-1.06^{\circ} \mathrm{C}$ ) during $1880-2012$ (IPCC 2014). This rise in the surface temperature could result in changing rainfall patterns globally (Wang et al. 2016). For instance, Trenberth et al. (2007) have observed a rising trend in rainfall over Asia, Australia, northern Europe, North and South America, whereas decreasing trend over the Mediterranean area, southern Asia, Sahel, western and southern Africa. Likewise, Longobardi and Villani (2010) and Altava-Ortiz et al. (2011) have shown a decreasing trend in average annual precipitation over Mediterranean basin and nearby regions. More recently, Adler et al. (2017) have not detected any significant trend in the global mean precipitation, however, a rising trend over tropical oceans and a declining trend over certain mid-latitudes areas has been detected. Nicholson et al. (2018) and Caloiero et al. (2018) have detected a significant downward trend in annual rainfall over West Africa, North Africa, and eastern Mediterranean. Besides, several other attempts have been made to examine the possible influences of changing climate on spatial and temporal rainfall trends (Loo et al. 2015; Mayowa et al. 2015; Xiao et al. 2016; Hu et al. 2017; Sein et al. 2018; Biasutti 2019; Haag et al. 2019; Sa'adi et al. 2019; Gebrechorkos et al. 2019).

Additionally, it has been well-recognized that the warming environment has enhanced the intensity of extreme precipitation more rapidly than mean precipitation (Kharin et al. 2013; Boucher 2013; Berg 2013; Fischer and Knutti 2016; Myhre et al. 2019). Hartmann et al. (2013) have observed that the occurrence of extreme precipitation events has increased over larger land areas than it has decreased in the second half of 20 th century. Therefore, extreme precipitation has increasingly become an illuminating subject of research during the period of changing climate (Cammarano and Tian 2018, Dahal et al 2018). Researchers have continuously made efforts to examine the extreme precipitation trends in relation to changing climate (Dore 2005; Alexander et al. 2006; Fischer and Knutti 2014; Asadieh and Krakauer 2015; Westra et al. 2013). Apart from this, increasing trends in extreme rainfall events have been detected over different parts of the world, for example, Europe (van den Besselaar et al. 2013), North America (Villarini and Vecchi 2012; Donat et al. 2013; Easterling et al. 2017), South America (Donat et al. 2013, Skansi et al. 2013), south eastern South America (Wu Y and Polvani 2017), Australia (Laz et al. 2014; Herath et al. 2017), South Asia (Sheikh et al. 2015) and south east Asia (Ge et al. 2019). Interestingly, most of the land areas have observed a rise in extreme rainfall events in summer season excluding Europe, which showed an increase during winters (Hartmann et al. 2013; Pinskwar et al. 2019).

In India, a number of efforts have been made to investigate the spatial and temporal trends in rainfall and related extremes. For instance, Guhathakurta and Rajeevan (2006) have not observed any trend in south west monsoon season rainfall over Indian region, but noticed substantial regional differences. Naidu et al. (2009) have observed a rise in summer monsoon rainfall in south India, whereas a decrease in northern India. Nonetheless, for India as a whole, the summer monsoon rainfall has not shown any trend (Kumar et al., 2010; Jain and Kumar, 2012), while Ghosh et al. (2009) have shown mixed trends in rainfall occurrence over different regions in India. Kumar et al. (2010) have shown a decline in annual and monsoon rainfall, while a rise in winter, pre- and post-monsoon seasons for India as a whole. However, these trends are statistically insignificant. Jain et al. (2013) have not detected any significant trend in annual rainfall occurrence over north east India, although seasonal trends have been detected. However, several researchers have shown a substantial rise in number and magnitude of extreme rainfall events over the Indian region (Goswami et al. 2006; Joshi and Rajeevan 2006; Krishnamurthy et al. 2009; Pattanaik and Rajeevan 2010). Conversely, Guhathakurta et al. (2011) have detected a decline in extreme rainfall events over central and north India, whereas an increase over peninsula, eastern and north eastern parts of India. Recently, Mukherjee et al. (2017) have noticed a significant rising trend in number of extreme rainfall events and ascribed it to increasing anthropogenic warming. Apart from this, numerous efforts have been done on the spatial and temporal pattern of rainfall and related extreme events for different states of India in recent times such as Kerala (Krishnakumar et al. 2009; Pal and Al-Tabbaa 2009; Pal and Al-Tabbaa 2011; Nair et al. 2014; Thomas and Prasannakumar 2016), West Bengal (Chatterjee et al. 2016; Ghosh

Page $2 / 20$ 
2018; Kundu and Mondal 2019), Andhra Pradesh (Rao et al. 2009; Patakamuri et al. 2020), Madhya Pradesh (Duhan and Pandey 2013; Jana et al. 2017); Orissa (Patra et al. 2012), Uttarakhand (Kotal et al. 2014; Nandargi et al. 2016), Jammu and Kashmir (Kumar et al. 2009), Punjab (Gill et al. 2013), Assam (Deka et al. 2013), Gujarat (Lunagaria et al. 2015; Dave and James 2017; Dave et al. 2017), and Maharashtra (Ratna 2012; Sonar 2014; Ingle 2018).

The above review exhibits that researchers have extensively examined the trends and pattern of rainfall and related extreme events for the different parts of globe, including India. However, studies on trends and pattern of rainfall and related extreme events pertaining to the dryland ecosystem of India i.e., for Rajasthan state are less in number. Climate of the Rajasthan state is of monsoon type and receives the major part of annual rainfall during the south west monsoon. The insufficient and erratic rainfall in many parts of the state constitutes a threat to agriculture. The distribution of rainfall in dryland ecosystem of Rajasthan is highly uneven and changes significantly from region to region and year to year (Pingale et al. 2014). Also, the state has been characterized by highest chances of rainfall deficiencies and drought occurrence (Rathore 2005). The region is highly dependent upon rainfall as it is an important source of groundwater recharge. The long-term climatic changes related to rainfall may affect the agriculture and water resources of the state (Yadav et al. 2018). For that reason, some investigations have been attempted to examine the rainfall and related extreme events for this state (Rao et al. 2011, 2014; Singh et al. 2012; Pingale et al. 2014; Poonia et al. 2014; Machiwal and Jha 2017; Srivastava 2018; Meena et al. 2019). However, these studies are restricted to the analyses of a particular rainfall event, district, western arid region and short period of data. No study has presented a comprehensive examination of rainfall and heavy rainfall events over entire dryland ecosystem of Rajasthan state in north western India. Therefore, a detailed analysis of recent rainfall variability for this dryland ecosystem is required. In the light of these facts, the main objective of this study is to examine recent rainfall variability over dryland ecosystem of Rajasthan state in north western India.

\section{Study Area}

The Rajasthan state, situated in north western part of India, is the largest state of country. It covers a widespread area of $3,42,239 \mathrm{~km}^{2}$ occupying about 10.4 percent of the India's geographical extent. Geographically, the state extends between latitudes $23^{\circ} 30^{\prime}$ to $30^{\circ} 11^{\prime}$ north latitudes and $69^{\circ} 29^{\prime}$ to $78^{\circ} 17^{\prime} \mathrm{E}$ longitudes (Fig. 1). The altitude of terrain in the state varies from 6 to $1698 \mathrm{~m}$ amsl. The state has a variety of topographic features such as the Thar Desert in the north west, sandy plains in the north east, the Aravalli Hills (spreading from north east to south west) in the center, and south eastern plateau. The Thar Desert is India's largest desert, which covers approximately 70 percent area of the state.

The state has matchless climatological characteristics in the form of low, highly variable, erratic and ill-distributed rainfall, low humidity, high wind speed, high evaporation losses, and extremes of diurnal, seasonal and annual temperatures. The Aravalli Hills play a major role in the climatic pattern of Rajasthan due to its parallel running along the direction of the south west monsoon. The Arabian Sea branch of monsoon winds hit the eastern slope of these hills and the south eastern part gets sufficient rainfall, whereas the north western part remains dry (arid and semi-arid). However, the south eastern parts of the state are characterized by humid to very humid climatic conditions (Fig. 1).

The state is characterized by frequent droughts, lack of perennial rivers, scarce vegetal cover, nomadic population and dependency of human on animal rearing. Further, the state of Rajasthan has a predominantly agrarian society with agro-pastoral economy. Of the total cultivated area (approximately 20 million hectares), only 20 percent area is irrigated due to 1 percent of the country's total water resources availability in the state. The onset and duration of monsoon significantly controls the performance of rain fed kharif crops. The yields of crops are sensitive to rainfall and wetter years are associated with higher yields.

\section{Data And Methods}

\subsection{Data collection and database preparation}

In the present study, daily rainfall data of 33 stations has been used for 57-years period (1961-2017), which are well spread over the Rajasthan state (Fig. 1). The data has been acquired from the online portal of Department of Water Resources, Government of Rajasthan, Rajasthan, India (www.waterresources.rajasthan.gov.in). Apart from this, annual temperature data of 26 stations have been obtained from the Department of Agriculture, Government of Rajasthan, Rajasthan, India for the period 1979-2014. The geographical position (latitude and longitude) and elevation details of these stations have been given in Table 1. The major problem with the rainfall analyses' is the missing records. For that reason, out of more than 400 stations, only 33 stations that have smaller number of missing values, has been selected for this investigation. Further, in above dataset, the daily rainfall data is available from the year 1957; however, the year 1961 has been considered as base year, because the data has been found consistent for the selected 33 stations only after 1961. Few stations have missing rainfall observations which are filled-in before undertaking further analysis. The normal ratio method has been executed to estimate the missing values by choosing the rainfall amounts of three nearest stations. Distance matrix is structured for all stations based on their geographical positions to evaluate closeness of stations with each other. 
Table 1

Basic information of selected stations and station-wise rainfall characteristics over dryland ecosystem of north western India (1961-2017).

\begin{tabular}{|c|c|c|c|c|c|c|c|c|c|c|c|c|}
\hline Stations & Latitude & Longitude & $\begin{array}{l}\text { Elevation } \\
\text { (m) }\end{array}$ & $\begin{array}{l}\text { Mean } \\
\text { rainfall } \\
(\mathrm{mm})\end{array}$ & $\begin{array}{l}\text { Maximum } \\
\text { rainfall } \\
(\mathrm{mm})\end{array}$ & Year & $\begin{array}{l}\text { Minimum } \\
\text { rainfall } \\
(\mathrm{mm})\end{array}$ & Year & $\begin{array}{l}\text { SD } \\
(\mathrm{mm})\end{array}$ & $\mathrm{C}_{\mathrm{V}}$ & $\mathrm{C}_{\mathrm{K}}$ & $\mathrm{C}_{\mathrm{S}}$ \\
\hline Ajmer & $26^{\circ} 27^{\prime}$ & $74^{\circ} 37^{\prime}$ & 529 & 551.0 & 1163.0 & 1975 & 205.3 & 1987 & 194.7 & 35.34 & 1.07 & 0.85 \\
\hline Alwar & $27^{\circ} 34^{\prime}$ & $76^{\circ} 36^{\prime}$ & 282 & 662.8 & 1445.1 & 1996 & 223.8 & 1987 & 230.7 & 34.80 & 1.12 & 0.62 \\
\hline Banswara & $23^{\circ} 33^{\prime}$ & $74^{\circ} 27^{\prime}$ & 229 & 1070.1 & 2591.0 & 2006 & 509.8 & 1966 & 385.6 & 36.03 & 3.28 & 1.33 \\
\hline Baran & $24^{\circ} 52^{\prime}$ & $76^{\circ} 40^{\prime}$ & 290 & 850.2 & 1739.0 & 2013 & 254.0 & 2002 & 300.3 & 35.32 & 0.66 & 0.93 \\
\hline Barmer & $25^{\circ} 45^{\prime}$ & $71^{\circ} 24^{\prime}$ & 189 & 275.9 & 759.0 & 2006 & 37.1 & 1968 & 165.7 & 60.06 & 0.89 & 1.01 \\
\hline Bharatpur & $27^{\circ} 13^{\prime}$ & $77^{\circ} 30^{\prime}$ & 181 & 631.2 & 1041.0 & 2005 & 218.5 & 1978 & 172.7 & 27.36 & 0.06 & -0.26 \\
\hline Bhilwara & $25^{\circ} 44^{\prime}$ & $74^{\circ} 20^{\prime}$ & 417 & 664.8 & 1120.0 & 2006 & 307.0 & 2009 & 210.1 & 31.61 & -0.96 & 0.19 \\
\hline Bikaner & $28^{\circ} 01^{\prime}$ & $73^{\circ} 18^{\prime}$ & 235 & 271.8 & 482.2 & 1983 & 32.0 & 2002 & 104.6 & 38.51 & -0.45 & 0.16 \\
\hline Bundi & $25^{\circ} 27^{\prime}$ & $75^{\circ} 38^{\prime}$ & 345 & 710.7 & 1245.4 & 1996 & 275.5 & 2002 & 186.9 & 26.30 & 0.41 & 0.41 \\
\hline Chittaurgarh & $24^{\circ} 53^{\prime}$ & $74^{\circ} 38^{\prime}$ & 401 & 805.7 & 1556.5 & 2016 & 389.7 & 1965 & 216.5 & 26.88 & 1.78 & 0.95 \\
\hline Churu & $28^{\circ} 18^{\prime}$ & $74^{\circ} 58^{\prime}$ & 294 & 396.9 & 690.2 & 1977 & 165.0 & 1965 & 146.7 & 36.96 & -0.88 & 0.32 \\
\hline Dausa & $26^{\circ} 54^{\prime}$ & $76^{\circ} 20^{\prime}$ & 337 & 632.2 & 1363.2 & 1975 & 300.0 & 2002 & 238.9 & 37.79 & 1.82 & 1.25 \\
\hline Dhaulpur & $26^{\circ} 42^{\prime}$ & $77^{\circ} 53^{\prime}$ & 174 & 659.8 & 1319.6 & 2008 & 171.8 & 1978 & 241.8 & 36.65 & 0.65 & 0.62 \\
\hline Dungarpur & $23^{\circ} 51^{\prime}$ & $73^{\circ} 43^{\prime}$ & 293 & 767.8 & 1611.0 & 2006 & 319.0 & 2008 & 270.3 & 35.21 & 0.87 & 0.73 \\
\hline Ganganagar & $29^{\circ} 55^{\prime}$ & $73^{\circ} 53^{\prime}$ & 178 & 281.3 & 666.0 & 1983 & 78.6 & 1968 & 130.2 & 46.28 & 1.30 & 0.93 \\
\hline Hanumangarh & $29^{\circ} 35^{\prime}$ & $74^{\circ} 19^{\prime}$ & 182 & 248.6 & 547.0 & 2010 & 75.5 & 1974 & 108.6 & 43.68 & 0.16 & 0.53 \\
\hline Jaipur & $26^{\circ} 55^{\prime}$ & $76^{\circ} 50^{\prime}$ & 428 & 596.0 & 1155.8 & 1977 & 85.0 & 1984 & 230.1 & 38.62 & -0.04 & 0.41 \\
\hline Jaisalmer & $26^{\circ} 55^{\prime}$ & $70^{\circ} 55^{\prime}$ & 229 & 196.8 & 512.8 & 2006 & 26.4 & 1969 & 115.9 & 58.93 & 1.17 & 0.70 \\
\hline Jalor & $25^{\circ} 21^{\prime}$ & $72^{\circ} 37^{\prime}$ & 161 & 433.5 & 1047.4 & 1990 & 51.3 & 1969 & 242.1 & 55.86 & -0.07 & 0.81 \\
\hline Jhalawar & $24^{\circ} 36^{\prime}$ & $76^{\circ} 09^{\prime}$ & 317 & 936.1 & 1614.5 & 2006 & 375.0 & 1968 & 292.2 & 31.22 & -0.26 & 0.60 \\
\hline Jhunjhunun & $28^{\circ} 08^{\prime}$ & $75^{\circ} 23^{\prime}$ & 347 & 406.5 & 828.0 & 2010 & 123.0 & 2002 & 155.0 & 38.12 & -0.48 & 0.27 \\
\hline Jodhpur & $26^{\circ} 18^{\prime}$ & $73^{\circ} 02^{\prime}$ & 254 & 374.1 & 815.0 & 1990 & 91.0 & 2002 & 166.3 & 44.48 & -0.46 & 0.49 \\
\hline Karauli & $26^{\circ} 30^{\prime}$ & $76^{\circ} 01^{\prime}$ & 281 & 740.7 & 1329.4 & 1975 & 275.5 & 2017 & 256.4 & 34.63 & -0.56 & 0.35 \\
\hline Kota & $25^{\circ} 08^{\prime}$ & $76^{\circ} 05^{\prime}$ & 269 & 737.7 & 1475.5 & 1971 & 325.0 & 1965 & 231.2 & 31.35 & 0.48 & 0.57 \\
\hline Nagaur & $27^{\circ} 12^{\prime}$ & $74^{\circ} 45^{\prime}$ & 314 & 388.4 & 1259.0 & 1975 & 110.0 & 2009 & 200.8 & 51.71 & 5.66 & 1.82 \\
\hline Pali & $25^{\circ} 47^{\prime}$ & $73^{\circ} 20^{\prime}$ & 218 & 329.3 & 1018.6 & 1979 & 90.0 & 1972 & 432.9 & 52.01 & -0.26 & 0.68 \\
\hline Pratapgarh & $24^{\circ} 03^{\prime}$ & $74^{\circ} 47^{\prime}$ & 508 & 936.5 & 1668.7 & 1973 & 359.7 & 1966 & 298.7 & 31.90 & -0.30 & 0.43 \\
\hline Rajsamand & $25^{\circ} 45^{\prime}$ & $74^{\circ} 05^{\prime}$ & 552 & 553.0 & 1039.0 & 2010 & 190.0 & 1969 & 179.9 & 32.55 & 0.55 & 0.44 \\
\hline $\begin{array}{l}\text { Sawai } \\
\text { Madhopur }\end{array}$ & $25^{\circ} 59^{\prime}$ & $76^{\circ} 22^{\prime}$ & 360 & 790.3 & 1249.0 & 2016 & 295.0 & 1984 & 245.0 & 31.00 & -0.57 & -0.06 \\
\hline Sikar & $27^{\circ} 37^{\prime}$ & $75^{\circ} 09^{\prime}$ & 433 & 497.1 & 1090.0 & 1977 & 124.0 & 2009 & 225.5 & 45.38 & -0.26 & 0.52 \\
\hline Sirohi & $24^{\circ} 36^{\prime}$ & $72^{\circ} 43^{\prime}$ & 299 & 630.5 & 1577.6 & 1973 & 190.9 & 1987 & 320.5 & 50.83 & 0.63 & 0.94 \\
\hline Tonk & $26^{\circ} 10^{\prime}$ & $75^{\circ} 48^{\prime}$ & 281 & 631.3 & 1200.0 & 2013 & 221.3 & 2002 & 207.9 & 32.94 & 0.25 & 0.45 \\
\hline Udaipur & $24^{\circ} 11^{\prime}$ & $73^{\circ} 55^{\prime}$ & 591 & 594.5 & 1095.5 & 1973 & 215.1 & 1989 & 186.0 & 31.29 & -0.15 & 0.11 \\
\hline
\end{tabular}

Further, data quality check is essential before the investigation, as outliers can extremely affect the rainfall trends and patterns (You et al. 2008; Shahid et al. 2016). To ensure the homogeneity, subjective double mass curve method and objective student's t-test have been performed for 
rainfall time-series. The double mass curves of all stations have not shown any breakpoint and displayed more or less a straight line which indicates the homogeneity in the data. Similarly, student's t test has not revealed any break point or statistically significant difference in the rainfall time series at $95 \%$ confidence level. Apart from this, the daily rainfall data has been summed up to obtain monthly, seasonal and annual values. Seasonal analysis has been done for four seasons namely (a) winter (January-February), (b) pre-monsoon (March-May), (c) Monsoon (June-September) and (d) post-monsoon (October-December), as per categorization of India Meteorological Department (IMD).

\subsection{Methods}

After preparation of complete dataset, suitable statistical analysis such as sum, frequencies, percentage, mean, standard deviation (SD), coefficient of variation $(\mathrm{CV})$, skewness $\left(C_{s}\right)$ and kurtosis $\left(C_{k}\right)$ have been performed for each station for the period 1961-2017. Then, the excess and deficit rainfall years and heavy rainy days have been identified as follows:

\subsubsection{Identification of Excess and Deficit Rainfall Years}

In this study, a year has been identified as an excess (deficit) rainfall year, if rainfall is more (less) than one SD from mean (Pant and Rupa Kumar 1997). Statistically, an excess rainfall year can be expressed as:

$$
R_{i} \geq R_{m}+S_{d}
$$

1

and a deficit year can be expressed as:

$$
R_{i} \leq R_{m}-S_{d}
$$

2

where, $R_{i}=$ rainfall amount in a year $i, R_{m}=$ mean rainfall and $S_{d}=\mathrm{SD}$ of rainfall.

\subsubsection{Identification of Heavy Rainfall Events}

In this study, an event is considered as heavy rainfall event if rainfall occurs $>65 \mathrm{~mm}$ in 24 hours (Kumar and Singh 2018). The total heavy rainfall events recorded at a particular station have been summed up to obtain monthly, seasonal and annual events. The total number of heavy rainfall events recorded at different stations have been averaged to represent their frequency.

\subsubsection{Trend Detection Methods}

The non-parametric Mann-Kendall (MK) (Mann 1945; Kendall 1948) has been used to detect the trend in rainfall. This MK test has been found an excellent tool to examine the possible existence of significant trends in the time-series at various significance levels (Mayowa et al. 2015; Singh et al. 2020). The standard normal variable $Z$ has used to detect the trend and its significance level. The positive (negative) values of $Z$ show rising (declining) trend in the time-series. In this study, the existence of statistically significant positive or negative trend has been considered at $95 \%$ confidence level. The MK test is a rank-based test, which have been used extensively for the verification of autocorrelation in the data series (Duhan and Pandey 2013). The test shows that if the lag-1 serial coefficients of the data are not statistically significant, then the MK test has been performed without any modification to the original time series (Karpouzos et al. 2010; Luo et al. 2008; Pingale et al. 2014). However, the existence of an autocorrelation can increase the probability of detecting a significant trend (Bayazit and Onoz 2008). Therefore, in the present study, MK test has been applied after pre-whitening for all stations and seasons to eliminate the effect of autocorrelation in the data series (Von Storch 1995; Partal and Kahya 2006; Mohammad and Jha 2014). Also, the non-parametric Sen's Slope estimator (Sen 1968) has been used to detect the magnitude of the trend. It is closely associated to the MK test (Gilbert 1987) and provides a robust estimation of trend (Yue et al. 2002). Additionally, the parametric simple linear regression has also been used to detect the trend in time-series in this study. These three methods have been used widely for this purpose in the hydro-meteorological studies. A detailed discussion about these methods is available in (Deka et al. 2013; Pingale et al. 2014; Jaiswal et al. 2015; Mayowa et al. 2015; Singh et al. 2020). These tests have been performed by means of XLSTAT 2017 software.

\subsubsection{Spatial Interpolation}

To examine the spatial pattern of rainfall characteristics, the inverse distance weighting (IDW) interpolation technique has been used in this study. The IDW technique is a simple and widely used interpolation technique. This spatial interpolation technique considers the role of each input point by a standardized inverse of the distance from the control point to the interpolated point. This technique assumes that each input point has a local impact that diminishes with increase in remoteness. It weighs more on points nearer to the processing points, than those of far away. It means a rainfall or its derived quantity at any desired location is interpolated from the given data using weights that are based on the distance from each rainfall station and the desired location (Burrough and McDonnell, 1998). This technique gives a smooth pattern of rainfall along with undesirable troughs and peaks. The interpolation of rainfall characteristic using IDW technique has been done by ArcGIS 10.2 software.

Page 5/20 


\section{Results And Discussion}

\subsection{Temporal Variations}

\subsubsection{Annual Variations}

The mean annual rainfall over dryland ecosystem of Rajasthan during 1961-2017 has been demonstrated in Fig. 2. The time-series has exhibited a high interannual variability in mean annual rainfall (SD $=221.10, C V=37.90$ ) varying from $277 \mathrm{~mm}$ (in year 2002 ) to $839 \mathrm{~mm}$ (in year 1975) with a mean of about $583 \mathrm{~mm}$ (Fig. 2; Table 2). The lowest (highest) rainfall in the year 2002 (1975) may be attributed to the prevalence of strong El-Nino (La-Nina) conditions (Mahala et al. 2015; Bhardwaj et al. 2019). Similarly, $C_{k}$ and $C_{s}$ are the measures of data peakedness, flatness and symmetry and their values for normal data distribution is zero or near zero. The positive values of $C_{k}$ reveal the peaked distribution and vice versa. In the study area, Banswara (very humid) and Nagaur (semi-arid) stations have high $\mathrm{C}_{\mathrm{k}}$, whereas Bhilwara (humid) and Churu (semi-arid) have low $C_{k}$. All the stations except Bharatpur and Sawai Madhopur (humid region) have positive $C_{\mathrm{s}}$, which suggests that there is an increment in the amount of rainfall than normal in all over the study area. It has been observed from the analysis that most of the rainfall deficit years such as 1965, 1969, 1972, 1987, 2002 and 2009 have occurred with El-Nino years (Table 3) (Mahala et al. 2015; Bhardwaj et al. 2019). The El-Nino years have disturbed the Indian monsoon badly and affected the agriculture system specifically in the Rajasthan state which is completely dependent on south west monsoon for arrival of rainfall. However, the mean annual rainfall has shown a marginal non-significant upward trend over the dryland ecosystem. Interestingly, three years running average has shown a cyclic pattern of mean annual rainfall under the changing climatic conditions. The mean annual rainfall has revealed a significant rising trend in arid and semi-arid regions except Pratapgarh stations situated in the very humid region of the state, which has been found consistent with Singh et al. (2001) (Fig. 3). Apart from this, most of the stations located in semi-arid, sub-humid and humid regions have shown increasing non-significant trends, whereas eastern and south eastern parts have shown non-significant decreasing trends. Rest of the regions have shown almost constant trends in the mean annual rainfall.

Table 2

Mean (M), standard deviation (SD), coefficient of variation (CV), kurtosis (CK), skewness (CS), Mann Kendall Test (Z), Sen's Slope estimator () and regression ( $\mathrm{R}$ ) of monthly, seasonal and annual rainfall over dryland ecosystem of north western India $(1961-2017)$

\begin{tabular}{|c|c|c|c|c|c|c|c|c|c|}
\hline \multicolumn{10}{|c|}{$\beta$} \\
\hline \multirow[t]{2}{*}{ Time } & & & $\mathrm{C}_{\mathrm{V}}$ & $\mathrm{C}_{\mathrm{K}}$ & $\mathrm{C}_{\mathrm{S}}$ & & Z & $\beta$ & $\mathrm{R}$ \\
\hline & $(\mathrm{mm})$ & $(\mathrm{mm})$ & & & & Annual & & & \\
\hline January & 4.69 & 6.08 & 129.66 & 3.96 & 2.00 & 0.80 & 0.39 & 0.01 & 0.39 \\
\hline February & 6.16 & 8.46 & 137.35 & 2.23 & 1.76 & 1.05 & 0.17 & 0.00 & 0.30 \\
\hline March & 5.06 & 10.46 & 206.63 & 19.38 & 4.23 & 0.86 & 0.88 & 0.01 & 0.61 \\
\hline April & 4.19 & 6.33 & 151.03 & 10.93 & 2.91 & 0.71 & $2.51^{\star}$ & $0.03^{\star}$ & 0.14 \\
\hline May & 12.60 & 10.83 & 85.94 & -0.33 & 0.87 & 2.15 & 1.09 & 0.06 & 0.45 \\
\hline June & 61.88 & 36.39 & 58.8 & -0.07 & 0.54 & 10.55 & 1.87 & 0.55 & 0.08 \\
\hline July & 195.90 & 64.07 & 32.71 & 0.10 & -0.58 & 33.39 & 0.98 & 0.58 & 0.35 \\
\hline August & 194.30 & 74.12 & 38.15 & -0.86 & 0.22 & 33.12 & 0.08 & 0.08 & 0.80 \\
\hline September & 80.85 & 53.02 & 65.58 & 1.96 & 0.95 & 13.78 & -0.25 & -0.11 & 0.39 \\
\hline October & 12.13 & 17.74 & 146.28 & 3.25 & 1.99 & 2.07 & -0.07 & 0.00 & 0.77 \\
\hline November & 5.98 & 14.20 & 237.46 & 8.41 & 3.00 & 1.02 & -0.70 & 0.00 & 0.74 \\
\hline December & 2.88 & 6.06 & 210.27 & 16.99 & 3.77 & 0.49 & 0.24 & 0.00 & 0.36 \\
\hline Winter (January-February) & 10.85 & 5.35 & 49.31 & -0.58 & 0.50 & 1.85 & 1.23 & 0.07 & 0.18 \\
\hline Pre-monsoon (March-May) & 21.86 & 7.98 & 36.51 & -0.53 & 0.53 & 3.73 & 1.16 & 1.40 & 0.19 \\
\hline Monsoon (June-September) & 532.93 & 213.53 & 40.07 & -0.48 & 0.14 & 90.85 & $1.65+$ & $0.15+$ & 0.44 \\
\hline Post-monsoon (October- December) & 21.00 & 9.61 & 45.74 & -0.57 & 0.34 & 3.58 & -0.42 & -0.04 & 0.82 \\
\hline Annual & 583.40 & 221.10 & 37.90 & -0.61 & 0.09 & 100.00 & 1.30 & 1.60 & 0.39 \\
\hline Significant at $95 \%$ confidence level & & & & & & & & & \\
\hline
\end{tabular}


Table 3

Excess and deficient rainfall years over dryland ecosystem of north western India (1961-2017)

\begin{tabular}{|lllllllllll|}
\hline Annual & \multicolumn{3}{c}{ Winter } & \multicolumn{3}{c}{ Pre-Monsoon } & \multicolumn{2}{c|}{ Monsoon } & \multicolumn{2}{c|}{ Post-Monsoon } \\
\hline Excess & Deficit & Excess & Deficit & Excess & Deficit & Excess & Deficit & Excess & Deficit \\
\hline 1961 & 1965 & 1970 & 1967 & 1967 & 1972 & 1961 & 1965 & 1974 & - \\
\hline 1973 & 1966 & 1979 & 1974 & 1982 & 1984 & 1973 & 1968 & 1976 & - \\
\hline 1975 & 1968 & 1986 & 2000 & 1983 & 2010 & 1975 & 1974 & 1979 & - \\
\hline 1976 & 1969 & 1990 & 2006 & 2001 & - & 1976 & 1979 & 1982 & - \\
\hline 1977 & 1972 & 1995 & - & 2008 & - & 1977 & 1985 & 1985 & - \\
\hline 1990 & 1980 & 2003 & - & 2014 & - & 1990 & 1987 & 1992 & - \\
\hline 1996 & 1987 & 2007 & - & 2015 & - & 1994 & 1989 & 1997 & - \\
\hline 2011 & 1989 & 2013 & - & - & - & 1996 & 2000 & 1998 & - \\
\hline 2013 & 2000 & 2014 & - & - & - & 2006 & 2002 & 2010 & - \\
\hline 2016 & 2002 & - & - & - & - & 2011 & 2009 & - & - \\
\hline- & 2009 & - & - & - & - & 2013 & - & - & - \\
\hline- & - & - & - & - & - & 2016 & - & - & - \\
\hline
\end{tabular}

Temperature is an important meteorological variable after rainfall. A significant change in temperature can pose a serious threat to agriculture, vegetation, habitat and biodiversity of a place (Mishra 2018). Therefore, in this study, a temporal distribution of annual mean, maximum, and minimum temperature has been undertaken, which revealed a non-significant increasing trend in most parts of the state (Fig. 4). These results have been found consistent with that reported by Roy (2015), Sharma et al. (2017) and Mehta and Yadav (2019). Pingale et al. (2014) and Roy (2015) have attributed these warming trends to increasing anthropogenic activities, namely, land use/cover changes, industrialization and urbanization. Generally, a rise in temperature is directly associated with rising evapotranspiration rates which further results in increasing rainfall trends. Previously, several such studies have revealed similar results in different parts of India (Singh et al. 2008a, b; Jain et al. 2013; Pingale et al. 2014; Roy 2015). In a study over the dryland ecosystem, Mishra (2018) have concluded that a change in climatic conditions leads to a significant change in rainfall, temperature and evapotranspiration rates, which in turn adversely affects the physical as well as economic landscapes of an area.

\subsubsection{Seasonal Variations}

The mean seasonal rainfall during different seasons over dryland ecosystem of Rajasthan during 1961-2017 has been displayed in Table 2. Approximately, 90 percent of total annual rainfall over the dryland ecosystem has occurred during monsoon season. Remaining rainfall (less than 10 percent) has occurred in three seasons i.e. winter, pre-monsoon and post-monsoon. Winter season has accounted only about 2 percent rainfall. Pre- and post-monsoon seasons have accounted remaining 8 percent (4 percent each) rainfall. The values of SD have been found very small during winter $(S D=5.35)$, pre-monsoon $(S D=7.98)$ and post-monsoon $(S D=9.61)$ seasons due to very less amount of rainfall than monsoon season (SD = 213.53) (Table 2). Interestingly, the dryland ecosystem as a whole has shown a marginal non-significant increase in rainfall amounts during winter, pre-monsoon and monsoon seasons, whereas post-monsoon season has shown a marginal non-significant decrease (Fig. 5). Like annual pattern, three year running average has exhibited a clear cyclic pattern in rainfall occurrence during monsoon season over Rajasthan. Likewise, all the stations have shown positive trends in mean rainfall except three stations namely Jalor, Pratapgarh and Udaipur during pre-monsoon season. Further, the detected increasing or decreasing trend in the occurrence of rainfall during different seasons has not been found statistically significant.

\subsubsection{Monthly Variations}

The mean monthly rainfall over dryland ecosystem of Rajasthan during 1961-2017 has been shown in Table 2. Monthly rainfall has exhibited a wide variation in its occurrence. Remarkably, only two months (July and August) have accounted approximately two-third of total annual rainfall, whereas December month has accounted only about 0.49 percent rainfall. Further, the SD and CV values have been found high during the July and August as these two months have received huge amount of rainfall with very high variability, whereas rainfall occurrence has been observed very less in rest of the months (Table 2). Further, the mean rainfall occurrence has been noticed less in April month, however, a rising trend has been observed in this month (Fig. 6; Table 2). The months of June and July have also shown insignificant increasing trends, whereas September, October and November months have shown an insignificant decreasing trend. Rests of the months have shown almost constant trends.

\subsection{Spatial Pattern}

Page $7 / 20$ 


\subsubsection{Annual Pattern}

The spatial pattern of mean annual rainfall over dryland ecosystem in north western India during 1961-2017 has been displayed in Fig. 7a. The mean annual rainfall has exhibited an increasing rainfall gradient from arid and semi-arid to humid and very humid regions. The mean annual rainfall occurrence over entire arid and semi-arid regions has been found less than $400 \mathrm{~mm}$, whereas it has been more than $850 \mathrm{~mm}$ over the south eastern parts located in the very humid regions. This decline in average annual rainfall from east to west is mainly associated with the presence of Aravalli Mountains spreading north east to south west in central Rajasthan (Yadav et al .2012). The Arabian Sea branch of monsoon winds hit the eastern slope of these hills and the south eastern part receives ample rainfall, while north western parts remain dry (Dutta et al. 2015). The moisture loss of monsoonal winds with distance also reduces the rainfall amounts towards westward from south east. The lowest mean annual rainfall has occurred over Jaisalmer station (196.81 mm), whereas highest over Banswara station (1070.18 mm) during 57 -years study period (Table 1). The spatial pattern of CV has exhibited almost opposite pattern to the mean annual rainfall (Fig. 7b). The higher (above 50 percent) values of CV have been noticed over the west and north west, whereas lower (below 35 percent) over east and south east. Exceptionally, the $\mathrm{CV}$ value has been found very high at Barmer station (about 60 percent), whereas it is just about 26 percent at Bundi station (Table 1). The higher CV values in the arid and semi-arid regions of the state have indicated high annual variability of rainfall. Conversely, the annual variability of rainfall has been observed relatively less in the areas of high rainfall. Hence, lack of rainfall and high variability are responsible for frequent occurrence of drought conditions (once in 2-3 years) over arid and semi-arid regions. These results are in correspondence with Narain et al. (2006) with respect to dryland ecosystem.

The spatial pattern of annual rainfall trends and magnitude during 1961-2017 detected by the MK test and Sen's slope estimator has been presented in Fig. 7c. Interestingly, majority of stations (23 stations; 70 percent) in the Rajasthan state have recorded positive trend in mean annual rainfall. Among these 23 stations, five stations namely Barmer, Churu, Ganganagar, Jaisalmer and Pratapgarh have observed statistically significant positive trends. These results have been found in agreement with previous studies (Pant and Hingane 1988; Singh et al. 2001). The magnitude of significant increasing trend has varied from $5.34 \mathrm{~mm} /$ year (Pratapgarh station) to $2.17 \mathrm{~mm} /$ year (Jaisalmer station). Majority of stations positioned in western parts of this dryland ecosystem have shown increasing trends, consistent with Kumar et al. (2010), Mondal et al. (2015) and Meena et al. (2019). Earlier, Lal et al. (2001) have also projected that the western arid region of India could receive higher than normal rainfall in warming climate. This rising trend in mean annual rainfall over western arid region, which is considered to be the most drought prone, could be extremely beneficial for agriculture as well as recharging of groundwater. However, these results are in contrast with Pingale et al. (2014) and Singh and Kumar (2015), who have shown a decline in mean annual rainfall over western parts of the state. Conversely, some stations located in the eastern parts of the state have recorded a non-significant decreasing trend, consistent with Kumar et al. (2010), Mondal et al. (2015) and Mundetia and Sharma (2015). However, no station has shown statistically significant declining trend in mean annual rainfall during 1961-2017. Additionally, the arid and semi-arid regions of the state have observed the maximum percent change in rainfall than humid and subhumid regions (Fig. $7 d$ ). Jaisalmer station has shown the highest percent increase (63 percent) in mean annual rainfall during the study period 1961-2017.

\subsubsection{Seasonal Pattern}

The seasonal pattern of rainfall over dryland ecosystem in north western India during 1961-2017 has been displayed in Fig. 8. During winter season, the entire state has received less than $20 \mathrm{~mm}$ rainfall. The northern and north eastern parts have received rainfall between 10 to $20 \mathrm{~mm}$ and extreme western parts receive less than $5 \mathrm{~mm}$ during this season (Fig. 8a). During pre-monsoon season, the pattern of rainfall has appeared almost identical to the winter season, however, rainfall has slightly increased over all parts of the state (Fig. 8b). The northern parts receive approximately $30 \mathrm{~mm}$ mean rainfall during this season. During these two seasons, the northern and north eastern parts of the state have observed some amount of rainfall, which may be attributed to the western disturbances and associated thunderstorm activity over this region (Bhardwaj and Singh 2018; Singh and Bhardwaj 2019). The rainfall pattern during monsoon and post-monsoon seasons has been found almost similar, with higher concentration over the eastern to south eastern parts of the state and a consistent decrease towards westward and north westward (Fig. 8c-d). During monsoon season, rainfall amount has ranged from approximately 900 mm in south eastern parts to less than 300 $\mathrm{mm}$ over western and north western parts. The entire state has received the rainfall from the summer monsoonal winds during this season. As about 91 percent of total annual rainfall has occurred in this season, therefore, the rainfall pattern of monsoon season is almost similar to the pattern of mean annual rainfall. The moisture loss of monsoonal winds with distance and Aravalli Mountains reduces the rainfall occurrence towards westward from southeast. During post-monsoon season, less than $15 \mathrm{~mm}$ of rainfall has occurred in western parts and about $30 \mathrm{~mm}$ over south eastern parts. Further, the spatial pattern of CV for different seasons has shown opposite pattern to the mean seasonal rainfall (Figure not shown). The variability of rainfall occurrence has been found comparatively high over the parts of less rainfall and vice-versa. The values of CV have been observed very less over all parts during monsoon season, which may be accredited to the higher occurrence of rainfall with summer monsoon. The values of CV have been found very high over entire state during other three seasons namely winter, pre-monsoon and post-monsoon seasons due to very less and erratic rainfall.

The spatial pattern of seasonal rainfall trends and magnitude during 1961-2017 detected by the MK test and Sen's slope estimator has been shown in Fig. 9. During winter season, all the stations in the study area have shown non-significant positive trends in mean rainfall except Nagaur

Page $8 / 20$ 
(Fig. 9a). A significant increasing trend in rainfall has been detected in humid and semi-arid regions of the state during pre-monsoon season (Fig. 9b). The magnitude of increasing trend has varied from $0.60 \mathrm{~mm} /$ year (Churu station) to $0.12 \mathrm{~mm} /$ year (Pali station). During monsoon season, majority of stations located in arid region (western parts) of Rajasthan have shown increasing trends in rainfall (Fig. 9c). A significant rising trend has been detected for stations like Ganganagar, Pratapgarh and Jaisalmer during this season. The magnitude of increasing rainfall trend has differed from $5.57 \mathrm{~mm}$ /year (Pratapgarh station) to $2.02 \mathrm{~mm}$ /year (Jaisalmer station). These findings have been found consistent with previous studies like Basistha et al. (2007), Kharol et al. (2013), Mondal et al. (2015) and Meena et al. (2019), and in contrast with Pingale et al. (2014). During post-monsoon season, majority of stations have shown non-significant negative trends (Fig. 9d). Further, the spatial pattern of percent change in rainfall amount during different seasons for the study period 1961-2017 has been shown in Fig. 10. During winter season, humid and very humid regions of the state and only three stations in arid region (Ganganagar, Churu and Sikar) have observed a positive change of more than 25 percent (Fig. 10a). During pre-monsoon season, a substantial change in the pattern of percent change in rainfall has been observed (Fig. 10b). The northern and north eastern parts have observed a positive change of more than 60 percent for the period $1961-2017$. During monsoon season, several stations located over eastern parts have shown a negative change in rainfall (Fig. 10c), consistent with Mundetia and Sharma (2015). However, no station has detected positive percent change in rainfall during post-monsoon season for a period of 57-years (Fig. 10d)

\subsubsection{Monthly Variations}

The spatial pattern of mean monthly rainfall over dryland ecosystem during 1961-2017 has been demonstrated in Fig. 11. In the months of January, February, March and April, the northern and north eastern parts have recorded the rainfall occurrence. However, the rainfall amount during these months has been found almost negligible. In the month of May, rainfall pattern has been found almost similar to April, but the amount of rainfall has increased. After the month of May, rainfall pattern has changed significantly. From the month June to August, rainfall has increased consistently over entire state. During these months, rainfall occurrence has been found comparatively higher over humid and very humid parts and a decrease towards westward and north westward. Then, the rainfall has started to lessen rapidly from September to December over all parts. Moreover, the spatial pattern of CV has exhibited the opposite pattern to mean monthly rainfall (Figure not shown). The values of CV have been found lowest over entire state in July month, whereas highest in December month.

\subsection{Trends in heavy rainfall events}

The annual maximum daily rainfall in Rajasthan during 1961-2017 has been displayed in (Fig. 12a). It has shown a non-significant positive trend, which signifies that the severity of the rainfall events has enhanced over dryland ecosystem in north western India. The maximum daily rainfall has been recorded highest in 1981 (550 mm) and lowest in 1989 (97 mm). The station-wise analysis of annual maximum daily rainfall has shown the mixed trends in rainfall without any significant rising or declining trend. The mean frequency of heavy rainfall events has been exhibited in Fig. 12b. The figure has revealed a positive trend in the frequency of heavy rainfall events over Rajasthan. The maximum number of heavy rainfall events have been observed in the years 1983 and 2006 (about 2.51 events), whereas lowest in the year 2002 (about 0.40 events). Additionally, the station-wise analysis of heavy rainfall events has shown almost constant trend except Bharatpur, Jaisalmer and Pratapgarh stations, which shows a significant rising trend, whereas Bundi station has shown significant decreasing trend (Figure not shown). The spatial pattern of heavy rainfall events over dryland ecosystem has been shown in Fig. 13. The pattern of heavy rainfall events has been found almost similar to the pattern of mean annual rainfall increasing from arid and semi-arid regions to humid and sub-humid regions. The mean frequency of heavy rainfall events has been noticed relatively higher over the humid and very humid parts (more than 2.50) and decreases towards arid and semi-arid parts (less than 1.0).

\section{Conclusions}

The distribution of rainfall over dryland ecosystem of Rajasthan is highly uneven due to its location and topography. Rainfall changes significantly from region to region and year to year having highest chances of deficiencies resulting occurrence of drought. But the studies pertaining to rainfall variability and trends over the dryland ecosystem are far less in number. To fill this research gap, an effort has been made in this study to examine the recent rainfall variability and trends for the period 1961-2017. The results of this study have revealed a significant rising trend over most of the arid and semi-arid regions except very humid region. The state has also recorded high interannual rainfall variability coupled with rainfall deficit years during El-Nino period. Remarkably, July and August months have accounted approximately two-third of total annual rainfall over the dryland ecosystem. Furthermore, the frequency of heavy rainfall events has shown a positive trend. The maximum number of heavy rainfall events have occurred in the years 1983 and 2006 (about 2.51 events), whereas lowest in the year 2002 (about 0.40 events). Apart from this, an increase in mean, minimum and maximum temperature has been detected in most parts of the state though statistically non-significant.

These above results show definite signs of change in rainfall and temperature over the state of Rajasthan, which can duly affect the climate as well as physical and economic landscapes. The overall increasing trends in rainfall may really be advantageous in the light of prevailing water scarcity problems over the dryland ecosystem. Interestingly, an increase in rainfall amount is anomalously due to increase in rainfall intensity, which produces large runoff volumes over a short period of time. Conversely, high rainfall variability may affect the net cultivated area. About

Page 9/20 
four million ha of culturable land has either been left uncultivated or has sowing been delayed during the year 2002 over the dryland ecosystem (Bhuiyan et al. 2006). Meanwhile, an increase in mean, maximum and minimum temperatures will lead to enhancement of aridity, which is most likely to affect the evapotranspiration, vegetation cover, crop growth and resultant agricultural productivity.

Furthermore, the findings of this study are important for water management as the water is key to human survival and all kinds of vegetative growth over the dryland ecosystem. Since the state holds only 1 percent of the total water resources of the country, the increasing trends of rainfall can hold good for recharging of groundwater resources. The increased availability of the rainwater resource will lessen the usual waterdeficit scenario in arid and semi-arid regions due to statistically significant positive rainfall trends. Apart from this, the increasing trends in rainfall and temperature at most of the stations conspicuously reveal a changing climate over the dryland ecosystem. A persistence of climate change in future over the ecosystem may result in damages to both soil and water resources, leading to desertification and decrease in agricultural productivity. The changing climate may also result in crisis of drinking water along with the scarcity of water for irrigation. Finally, the outcome of this study may prove to be useful to policy makers, hydrologists and water resource managers dealing with climate change in the state of Rajasthan for sustainable development and planning of water resources.

\section{Declarations}

\section{Acknowledgements}

The authors are grateful for the critical and constructive comments made by the anonymous reviewer, which really improved the quality of manuscript.

Author contribution $\quad$ D. Saini, analyzed data, did literature review, and drafted the initial manuscript. P. Bhardwaj provided research direction, and assisted in writing and editing of the manuscript. 0 . Singh took lead in the supervision, guided research direction, and assisted in the writing and editing of the manuscript. The listed authors have made a significant contribution to warrant their being part of authorship and have approved the work.

\section{Code availability Not applicable}

Funding Statement Not applicable

Data Availability The data will be made available on demand.

Ethics approval Not applicable

Consent to participate The authors express their consent to participate for research and review.

Consent for publication The authors express their consent for publication of research work.

Competing interests The authors declare no competing interests.

\section{References}

1. Adler RF, Gu G, Sapiano M, Wang JJ, Huffman GJ (2017) Global Precipitation: Means, variations and trends during the satellite era (19792014). Surv Geophys 38:679-699

2. Alexander LV et al (2006) Global observed changes in daily climate extremes of temperature and precipitation. J Geophys Res 111:D05109

3. Altava-Ortiz V, Llasat MC, Ferrari E, Atencia A, Sirangelo B (2011) Monthly rainfall changes in Central and Western Mediterranean basins, at the end of the 20th and beginning of the 21st centuries. Int J Climatol 31:1943-1958

4. Asadieh B, Krakauer NY (2015) Global trends in extreme precipitation: Climate models versus observations. Hydrol Earth Syst Sci 19:877891

5. Basistha A, Goel NK, Arya DS, Gangwar SK (2007) Spatial pattern of trends in Indian sub-divisional rainfall. Jalvigyan Sameeksha 22:47-57

6. Bayazit M, Onoz B (2008) To prewhiten or not to prewhiten in trend analysis? Hydrol Sci J 52:611-624

7. Berg P, Moseley C, Haerter JO (2013) Strong increase in convective precipitation in response to higher temperatures. Nat Geosci 6:181-185

8. Bhardwaj P, Pattanaik DR, Singh O (2019) Tropical cyclone activity over Bay of Bengal in relation to El Niño-Southern Oscillation. Int J Climatol 39:5452-5469

9. Bhardwaj P, Singh O (2018) Spatial and temporal analysis of thunderstorm and rainfall activity over India. Atmosfera 31:255-284

10. Bhuiyan C, Singh RP, Kogan FN (2006) Monitoring drought dynamics in the Aravalli region (India) using different indices based on ground and remote sensing data. Int J Appl Earth Obs Geoinf 8:289-302 
11. Biasutti M (2019) Rainfall trends in the African Sahel: Characteristics, processes, and causes. WIREs Clim Change 10:e591

12. Boucher $O$ et al (2013) Clouds and aerosols. In: Climate Change 2013: The physical science basis. In: Stocker TF, Qin D, Plattner GK, Tignor MMB, Allen SK, Boschung J, Nauels A, Xia Y, Bex V, Midgley PM (eds) Contribution of working group I to the fifth assessment report of the intergovernmental panel on climate change. Cambridge University Press, New York, USA, pp 571-657

13. Burrough PA, McDonnell RA (1998) Principles of Geographical Information Systems, Spatial Information Systems and Geostatistics. Oxford University Press, Oxford

14. Caloiero T, Caloiero P, Frustaci F (2018) Long-term precipitation trend analysis in Europe and in the Mediterranean basin. Water Environment Journal 32:433-445

15. Cammarano D, Tian D (2018) The effects of projected climate and climate extremes on a winter and summer crop in the southeast USA. Agric For Meteorol 248:109-118

16. Chatterjee S, Khan A, Akbari H, Wang Y (2016) Monotonic trends in spatio-temporal distribution and concentration of monsoon precipitation (1901-2002), West Bengal, India. Atmos Res 182:54-75

17. Dahal V, Gautam S, Bhattarai R (2018) Analysis of the long-term precipitation trend in Illinois and its implications for agricultural production. Water 10:433

18. Dave H, James ME (2017) Characteristics of intense rainfall over Gujarat State (India) based on percentile criteria. Hydrol Sci J 62:20352048

19. Dave H, James ME, Ray K (2017) Trends in intense rainfall events over Gujarat State (India) in the warming environment using gridded and conventional data. International Journal of Applied Environmental Sciences 12:977-998

20. Deka RL, Mahanta C, Pathak H, Nath KK, Das S (2013) Trends and fluctuations of rainfall regime in the Brahmaputra and Barak basins of Assam, India. Theoret Appl Climatol 114:61-71

21. Donat MG et al (2013) Updated analyses of temperature and precipitation extreme indices since the beginning of the twentieth century: the HadEX2 dataset. J Geophys Res 118:2098-2118

22. Dore MHI (2005) Climate change and changes in global precipitation patterns: What do we know? Environ Int 31:1167-1181

23. Duhan D, Pandey A (2013) Statistical analysis of long term spatial and temporal trends of precipitation during 1901-2002 at Madhya Pradesh, India. Atmos Res 122:136-149

24. Dutta D, Kundu A, Patel NR, Saha SK, Siddiqui AR (2015) Assessment of agricultural drought in Rajasthan (India) using remote sensing derived Vegetation Condition Index (VCI) and Standardized Precipitation Index (SPI). The Egyptian Journal of Remote Sensing Space Science 18:53-63

25. Easterling DR, Kunkel KE, Arnold JR, Knutson T, LeGrande AN, Leung LR, Vose RS, Waliser DE, Wehner MF (2017) Precipitation change in the United States. In: Wuebbles DJ, Fahey DW, Hibbard KA, Dokken DJ, Stewart BC, Maycock TK (eds) Climate science special report: fourth national climate assessment, Volume-1. U.S. Global Change Research Program, Washington, pp 207-230

26. Fischer EM, Knutti R (2016) Observed heavy precipitation increase confirms theory and early models. Nature Climate Change 6:986-991

27. Fischer EM, Knutti R (2014) Detection of spatially aggregated changes in temperature and precipitation extremes. Geophys Res Lett 41:547554

28. Ge F, Zhu S, Peng T, Zhao Y, Sielmann F, Fraedrich K, Zhi X, Liu X, Tang W, Ji L (2019) Risks of precipitation extremes over Southeast Asia: does $1.5^{\circ} \mathrm{C}$ or $2^{\circ} \mathrm{C}$ global warming make a difference? Environmental Research Letters 14:044015

29. Gebrechorkos SH, Hülsmann S, Bernhofer C (2019) Long-term trends in rainfall and temperature using high-resolution climate datasets in East Africa. Sci Rep 9:11376

30. Ghosh KG (2018) Analysis of rainfall trends and its spatial patterns during the last century over the Gangetic West Bengal, Eastern India. Journal of Geovisualization Spatial Analysis 2:15

31. Ghosh S, Luniya V, Gupta A (2009) Trend analysis of Indian summer monsoon rainfall at different spatial scales. Atmospheric Science Letters 10:285-290

32. Gilbert RO (1987) Statistical methods for environmental pollution monitoring. Van Nostrand Reinhold Company, New York

33. Gill KK, Kukal SS, Sandhu SS, Brar H (2013) Spatial and temporal variation of extreme rainfall events in Central Punjab. International Journal of Applied Engineering Research 8:1757-1764

34. Goswami BN, Venugopal V, Sangupta D, Madhusoodanan MS, Xavier PK (2006) Increasing trend of extreme rain events over India in a warming environment. Science 314:1442-1445

35. Guhathakurta P, Sreejith OP, Menon PA (2011) Impact of climate change on extreme rainfall events and flood risk in India. J Earth Syst Sci 120:359-373

36. Guhathakurta P, Rajeevan. M (2006) Trends in the rainfall pattern over India. NCC Research Report No 2/2006, May 2006, India Meteorological Department, pp 23

Page $11 / 20$ 
37. Haag I, Jones PD, Samimi C (2019) Central Asia's changing climate: How temperature and precipitation have changed across time, space, and altitude. Climate 7:123

38. Hartmann DL et al (2013) Observations: atmosphere and surface. In: Change TF, Qin SD, Plattner GK et al (eds) Climate change 2013: the physical science basis. Contribution of working group I to the fifth assessment report of the intergovernmental panel on climate. Cambridge University Press, Cambridge, pp 160-254

39. Herath SM, Sarukkalige R, Nguyen VTV (2017) Evaluation of empirical relationships between extreme rainfall and daily maximum temperature in Australia. J Hydrol 556:1171-1181

40. Hu Z, Zhou Q, Chen X, Qian C, Wang S, Li J (2017) Variations and changes of annual precipitation in Central Asia over the last century. Int J Climatol 37:157-170

41. Ingle ST, Patil SN, Mahale NK, Mahajan YJ (2018) Analyzing rainfall seasonality and trends in the North Maharashtra region. Environ Earth Sci 77:651

42. IPCC (2014) Summary for Policymakers. In: Climate Change 2014: Impacts, Adaptation, and Vulnerability. Contribution of Working Group II to the Fifth Assessment Report of the Intergovernmental Panel on Climate Change. Intergovernmental Panel on Climate Change. Cambridge University Press, Cambridge

43. Jain SK, Kumar V (2012) Trend analysis of rainfall and temperature data for India. Curr Sci 102:37-49

44. Jain SK, Kumar V, Saharia M (2013) Analysis of rainfall and temperature trends in northeast India. Int J Climatol 33:968-978

45. Jaiswal RK, Lohani AK, Tiwari HL (2015) Statistical Analysis for Change Detection and Trend Assessment in Climatological Parameters. Environmental Processes 2:729-749

46. Jana C, Alam NM, Mandal D, Shamim M, Kaushal R (2017) Spatio-temporal rainfall trends in the twentieth century for Bundelkhand region, India. Journal of Water Climate Change 8:441-455

47. Joshi UR, Rajeevan M (2006) Trends in precipitation extremes over India. 3/2006, National Climate Centre

48. Karpouzos DK, Kavalieratou S, Babajimopoulos C (2010) Trends analysis of precipitation data in Pieria region (Greece). European Water $30: 31-40$

49. Kendall MG (1948) Rank correlation methods. Griffin, London. https://doi.org/10.2307/2333282

50. Kharin VV, Zwiers FW, Zhang X, Wehner M (2013) Changes in temperature and precipitation extremes in the CMIP5 ensemble. Clim Change 119:345-357

51. Kharol SK, Kaskaoutis DG, Badarinath KVS, Sharma AR, Singh RP (2013) Influence of land use/land cover (LULC) changes on atmospheric dynamics over the arid region of Rajasthan state, India. Journal of Arid Environment 88:90-101

52. Kotal SD, Roy SS, Roy SKB (2014) Catastrophic heavy rainfall episode over Uttarakhand during 16-18 June 2013 -observational aspects. Curr Sci 107:234-245

53. Krishnakumar KN, Prasada Rao GSLHV, Gopakumar CS (2009) Rainfall trends in twentieth century over Kerala, India. Atmos Environ 43:1940-1944

54. Krishnamurthy CKB, Lall U, Kown HH (2009) Changing Frequency and Intensity of Rainfall Extremes over India from 1951 to 2003 . J Clim 22:4737-4746

55. Kumar D, Singh O (2018) Flood producing rainstorms over the Markanda catchment of north-west India: A hydrological study. Punjab Geographer 14:33-51

56. Kumar V, Jain SK (2009) Trends in seasonal and annual rainfall and rainy days in Kashmir valley in the last century. Quatern Int 212:64-69

57. Kumar V, Jain SK, Singh Y (2010) Analysis of long-term rainfall trends in India. Hydrol Sci J 55:484-496

58. Kundu SK, Mondal TK (2019) Analysis of long-term rainfall trends and change point in West Bengal, India. Theoret Appl Climatol 138:16471666

59. Lal M, Nozawa T, Emori S, Harasawa H, Takahashi K, Kimoto M, Abe-Ouchi A, Nkajima T, Takemura T, Numaguti A (2001) Future climate change: Implications for Indian summer monsoon and its variability. Curr Sci 81:1196-1207

60. Laz OU, Rahman A, Yilmaz A, Haddad K (2014) Trends in sub hourly, sub daily and daily extreme rainfall events in Eastern Australia. Journal of Water Climate Change 5:667-675

61. Longobardi A, Villani P (2010) Trend analysis of annual and seasonal rainfall time series in the Mediterranean area. Int J Climatol 30:15381546

62. Loo YY, Billa L, Singh A (2015) Effect of climate change on seasonal monsoon in Asia and its impact on the variability of monsoon rainfall in Southeast Asia. Geosci Front 6:817-823

63. Lunagaria MM, Dabhi HP, Pandey V (2015) Trends in the temperature and rainfall extremes during recent past in Gujarat. Journal of Agrometeorology 17:118-123

Page $12 / 20$ 
64. Luo Y, Lio S, Sheng L, Fu S, Liu J, Wang G, Zhou G (2008) Trends of precipitation in Beijing River basin, Guangdong Province, China. Hydrol Process 22:2377-2386

65. Machiwal D, Jha MK (2017) Evaluating persistence, and identifying trends and abrupt changes in monthly and annual rainfalls of a semiarid region in western India. Theoret Appl Climatol 128:689-708

66. Mahala BK, Nayak BK, Mohanty PK (2015) Impacts of ENSO and IOD on tropical cyclone activity in the Bay of Bengal. Nat Hazards 75:1105-1125

67. Mann HB (1945) Nonparametric tests against trend. Econometrica. https://doi.org/10.2307/1907187

68. Mayowa OO, Pour SH, Shahid S, Mohsenipour M, Harun SB, Heryansyah A, Ismail T (2015) Trends in rainfall and rainfall-related extremes in the east coast of peninsular Malaysia. J Earth Syst Sci 124:1609-1622

69. Meena HM, Machiwal D, Santra P, Moharana PC, Singh DV (2019) Trends and homogeneity of monthly, seasonal, and annual rainfall over arid region of Rajasthan, India. Theoret Appl Climatol 136:795-811

70. Mehta D, Yadav SM (2019) Trend detection in temperature using Mann-Kendall test: A case study to assess climate changes in Rajasthan state. International Conference (Hydraulics, Water Resources and Coastal Engineering), Osmania University, Hyderabad

71. Mishra (2018) Analysis of temperature and rainfall patterns of Rajasthan. International Journal of Environmental Sciences Natural Resources 10:4

72. Mohammad S, Jha MK (2014) Seasonal and annual precipitation time series trend analysis in North Carolina, United States. Atmos Res 137:183-194

73. Mondal A, Khare D, Kundu S (2015) Spatial and temporal analysis of rainfall and temperature trend of India. Theoret Appl Climatol 122:143158

74. Mukherjee S, Aadhar S, Stone D, Mishra V (2018) Increase in extreme precipitation events under anthropogenic warming in India. Weather Climate Extremes 20:45-53

75. Mundetia N, Sharma D (2015) Analysis of rainfall and drought in Rajasthan state, India. Global NEST Journal 17:12-21

76. Myhre G, Alterskjær K, Stjern CW, Hodnebrog Q, Marelle L, Samset BH, Sillmann J, Schaller N, Fischer E, Schulz M, Stohl A (2019) Frequency of extreme precipitation increases extensively with event rareness under global warming. Sci Rep 9:16063

77. Naidu CV, Durgalakshmi K, Krishna KM, Rao SR, Satyanarayana GC, Lakshminarayana P, Rao ML (2009) Is summer monsoon rainfall decreasing over India in the global warming era? J Geophys Res 114:D24

78. Nair A, Joseph KA, Nair KS (2014) Spatio-temporal analysis of rainfall trends over a maritime state (Kerala) of India during the last 100 years. Atmos Environ 88:123-132

79. Nandargi S, Gaur A, Mulye SS (2016) Hydrological analysis of extreme rainfall events and severe rainstorms over Uttarakhand, India. Hydrol Sci J 61:2145-2163

80. Narain P, Rathore LS, Singh RS, Rao AS (2006) Drought assessment and management in arid Rajasthan. Central arid zone research institute. Jodhpur and NCMRWF, Noida pp 64

81. Nicholson SE, Funk C, Fink AH (2018) Rainfall over the African continent from the 19th through the 21st century. Global Planet Change 165:114-127

82. Pal I, Al-Tabbaa A (2009) Trends in seasonal precipitation extremes-an indicator of 'climate change' in Kerala, India. J Hydrol 367:62-69

83. Pal I, Al-Tabbaa A (2011) Monsoon rainfall extreme indices and tendencies from 1954-2003 in Kerala, India. Clim Change 106:407-419

84. Pant GB, Hingane LS (1988) Climatic change in and around the Rajasthan desert during the 20th century. J Climatol 8:391-401

85. Pant GB, Rupa Kumar K (1997) Climates of South Asia. Wiley, Chichester

86. Partal T, Kahya E (2006) Trend analysis in Turkish precipitation data. Hydrol Process 20:2011-2026

87. Patakamuri SK, Muthiah K, Sridhar V (2020) Long-term homogeneity, trend, and change-point analysis of rainfall in the arid district of Ananthapuramu, Andhra Pradesh state, India. Water 12:211

88. Patra JP, Mishra A, Singh R, Raghuwanshi NS (2012) Detecting rainfall trends in twentieth century (1871-2006) over Orissa State, India. Clim Change 111:801-817

89. Pattanaik DR, Rajeevan M (2010) Variability of extreme rainfall events over India during southwest monsoon season. Meteorol Appl 17:88104

90. Pingale SM, Khare D, Jat MK, Adamowski J (2014) Spatial and temporal trends of mean and extreme rainfall and temperature for the 33 urban centers of the arid and semi-arid state of Rajasthan, India. Atmos Res 138:73-90

91. Pinskwar I, Chorynski A, Graczyk D, Kundzewicz ZW (2019) Observed changes in extreme precipitation in Poland: 1991-2015 versus 19611990. Theoret Appl Climatol 135:773-787 
92. Poonia S, Rao AS, Singh DV, Choudhary S (2014) Rainfall characteristics and meteorological drought in Hanumangarh district of arid Rajasthan. Annals of Plant Soil Research 16:279-284

93. Rao AS, Poonia S, Purohit RS, Choudhary S (2014) Rainfall characteristics and meteorological drought condition in Jhunjhunu district of western Rajasthan. Annals of Plant Soil Research 15:110-113

94. Rao V, Manikandan N, Singh NP, Bantilan MCS, Satyanarayana T, Rao AVMS, Rao GGSN (2009) Trends of heavy rainfall events in Anantapur and Mahbubnagar districts of Andhra Pradesh. Journal of Agrometeorology 11:195-199

95. Rao VB, Arai E, Franchito SH, Shimabukuro YE, Ramakrishna SSVS, Naidu CV (2011) The Thar, Rajputana desert unprecedented rainfall in 2006 and 2010: effect of climate change? Geofísica Internacional 50:363-370

96. Rathore MS (2005) State level analysis of drought policies and impacts in Rajasthan, India, International Water Management Institute, Working paper 93, Drought Series Paper No. 6, Colombo, Sri Lanka

97. Ratna SB (2012) Summer monsoon rainfall variability over Maharashtra, India. Pure appl Geophys 169:259-273

98. Roy AD (2015) Trend detection in temperature and rainfall over Rajasthan during the last century. Asian Journal of Research in Social Sciences Humanities 5:12-26

99. Sa'adi Z, Shahid S, Ismail T, Chung ES, Wang XJ (2019) Trend analysis of rainfall and rainfall extremes in Sarawak, Malaysia using modified Mann-Kendall test. Meteorol Atmos Phys 131:263-277

100. Sein SS, Chidthaisong A, Oo KL (2018) Observed trends and changes in temperature and precipitation extreme indices over Myanmar. Atmosphere 9:477

101. Sen PK (1968) Estimates of the regression coefficient based on Kendall's Tau. J Am Stat Assoc 63:1379-1389

102. Shahid S, Wang XJ, Harun SB, Shamsudin SB, Ismail T, Minhans A (2016) Climate variability and changes in the major cities of Bangladesh: Observations, possible impacts and adaptation. Reg Environ Change 16:459-471

103. Sharma A, Sharma D, Panda SK, Dubey SK, Pradhan RK (2017) Investigation of temperature and its indices under climate change scenarios over different regions of Rajasthan state in India. Global Planet Change 161:82-96

104. Sheikh MM, Manzoor N, Ashraf J, Adnan M, Collins D, Hameed S, Manton MJ, Ahmed AU, Baidya SK, Borgaonkar HP, Islam N, Jayasinghearachchi D, Kothawale DR, Premalal KHMS, Revadekar JV, Shrestha ML (2015) Trends in extreme daily rainfall and temperature indices over South Asia. Int J Climatol 35:1625-1637

105. Singh B, Rajpurohit D, Vasishth A, Singh J (2012) Probability analysis for estimation of annual one day maximum rainfall of Jhalarapatan area of Rajasthan, India. Plant Archives 12:1093-1100

106. Singh O, Bhardwaj P (2019) Spatial and temporal variations in the frequency of thunderstorm days over India. Weather 74:138-144

107. Singh O, Kasana A, Singh KP, Sarangi A (2020) Analysis of drivers of trends in groundwater levels under rice-wheat ecosystem in Haryana, India. Nat Resour Res 29:1101-1126

108. Singh P, Kumar V, Thomas T, Arora M (2008a) Basin-wide assessment of temperature trends in northwest and central India. Hydrol Sci J 53:421-433

109. Singh P, Kumar V, Thomas T, Arora M (2008b) Changes in rainfall and relative humidity in river basins in northwest and central India. Hydrol Process 22:2982-2992

110. Singh RB, Kumar A (2015) Climate variability and water resource scarcity in drylands of Rajasthan, India. Geoenvironmental Disasters 2:7

111. Singh RS, Narain P, Sharma KD (2001) Climate changes in Luni river basin of arid western Rajasthan (India). Vayu Mandal 31:103-106

112. Skansi MM et al (2013) Warming and wetting signals emerging from analysis of changes in climate extreme indices over South America. Global Planetary Change 100:295-307

113. Sonar RB (2014) Observed trends and variations in rainfall events over Ratnagiri (Maharashtra) during southwest monsoon season. Mausam 65:171-178

114. Srivastava K, Pradhan D (2018) Real-time extremely heavy rainfall forecast and warning over Rajasthan during the monsoon season (2016). Pure appl Geophys 175:421-448

115. Thomas J, Prasannakumar V (2016) Temporal analysis of rainfall (1871-2012) and drought characteristics over a tropical monsoon dominated State (Kerala) of India. J Hydrol 534:266-280

116. Trenberth KE, Jones PD, Ambenje P, Bojariu R, Easterling D, Klein Tank A, Parker D, Rahimzadeh F, Renwick JA, Rusticucci M, Soden B, Zhai P (2007) Observations: surface and atmospheric climate change. In: Solomon, Qin SD, Manning M, Chen Z, Marquis M, Averyt KB, Tignor M, Miller HL (eds) climate change 2007: the physical science basis. contribution of working group I to the fourth assessment report of the intergovernmental panel on climate change. Cambridge University Press, Cambridge

117. van den Besselaar EJM, Klein AMG, Buishand TA (2013) Trends in European precipitation extremes over 1951-2010. Int J Climatol 33:26822689

Page $14 / 20$ 
118. Villarini G, Vecchi GA (2012) Twenty-first-century projections of North Atlantic tropical storms from CMIP5 models. Nature Climate Change 2:604-607

119. Von Storch H (1995) Misuses of statistical analysis in climate research. Applications of statistical techniques. Berlin, New York, Analysis of climatic variability

120. Wang XJ, Zhang JY, Shahid S, Guan EH, Wu YX, Gao J, He RM (2016) Adaptation to climate change impacts on water demand. Mitig Adapt Strat Glob Change 21:81-99

121. Westra S, Alexander LV, Zwiers FW (2013) Global increasing trends in annual maximum daily precipitation. J Clim 26:3904-3918

122. Wu Y, Polvani LM (2017) Recent trends in extreme precipitation and temperature over southeastern South America: The dominant role of stratospheric ozone depletion in the CESM large ensemble. J Clim 30:6433-6441

123. Xiao Y, Zhang X, Wan H, Wang Y, Liu C, Xia J (2016) Spatial and temporal characteristics of rainfall across Ganjiang river basin in China. Meteorol Atmos Phys 128:167-179

124. Yadav RK, Rupa Kumar K, Rajeevan M (2012) Characteristic features of winter precipitation and its variability over northwest India. J Earth Syst Sci 121:611-623

125. Yadav SK, Gautam S, Rawat S (2018) Rainfall variability estimation for western Rajasthan, India. International Journal of Current Microbiology Applied Sciences 7:4344-4348

126. You Q, Kang S, Aguilar E, Yan Y (2008) Changes in daily climate extremes in the eastern and central Tibetan 31 plateau during 1961-2005. J Geophys Res 113:D07101

127. Yue S, Pilon P, Cavadias G (2002) Power of the Mann-Kendall and Spearman's Rho tests for detecting monotonic trends in hydrologic series. J Hydrol 259:254-271

\section{Figures}

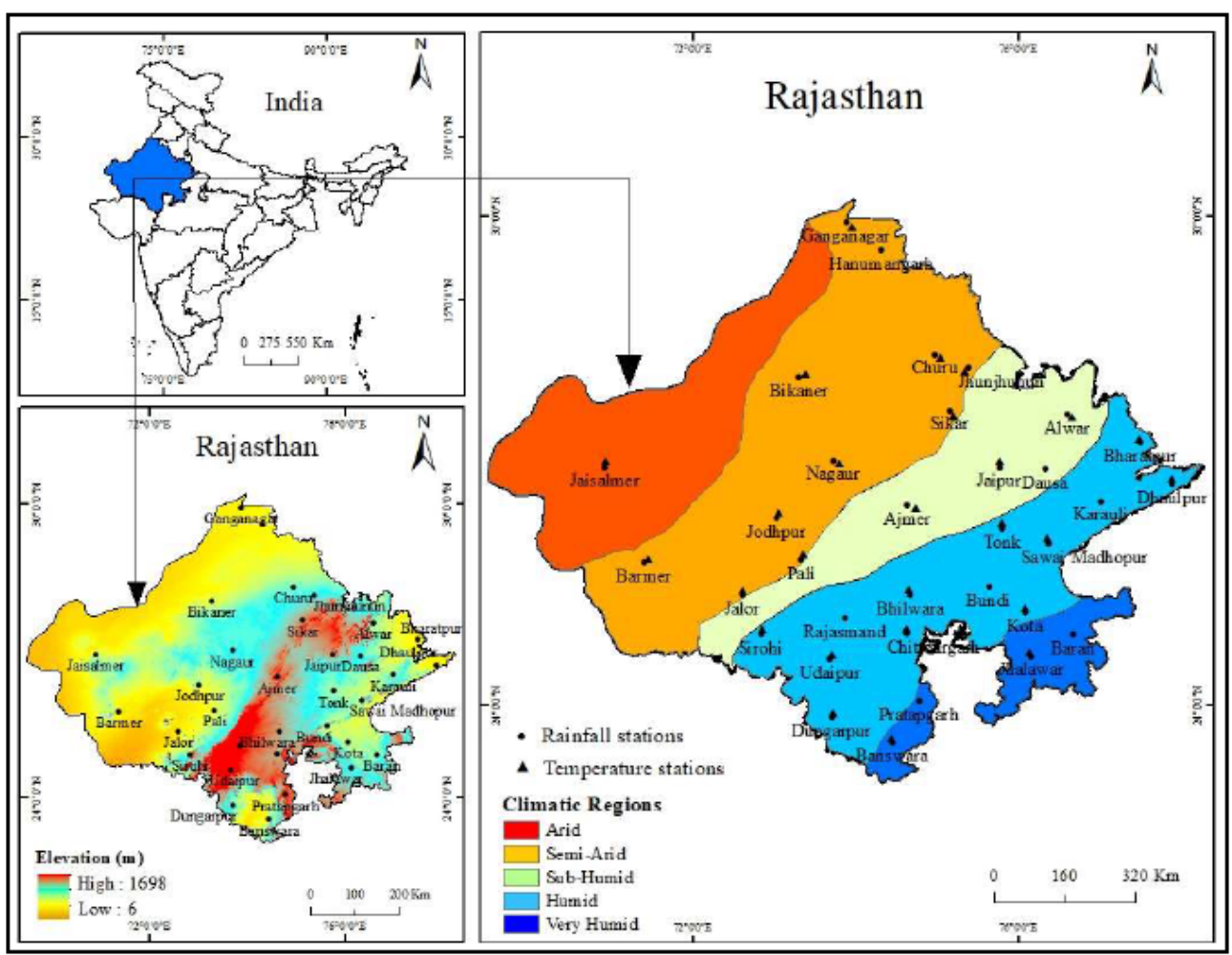

\section{Figure 1}

Map showing the position of study area in India and geographical location of selected rainfall and temperature stations. 


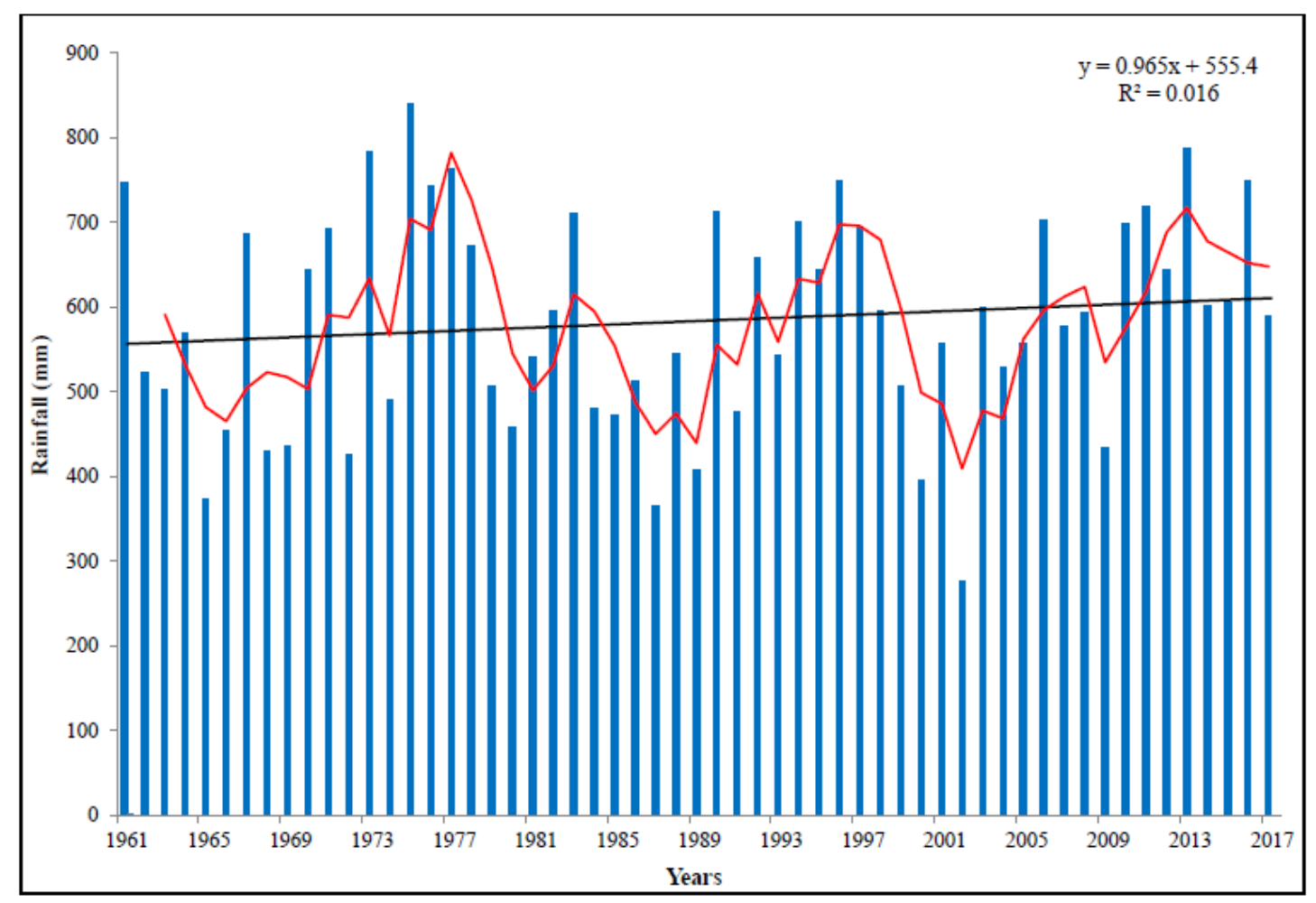

Figure 2

Temporal distribution of mean annual rainfall over dryland ecosystem of north western India (1961-2017).

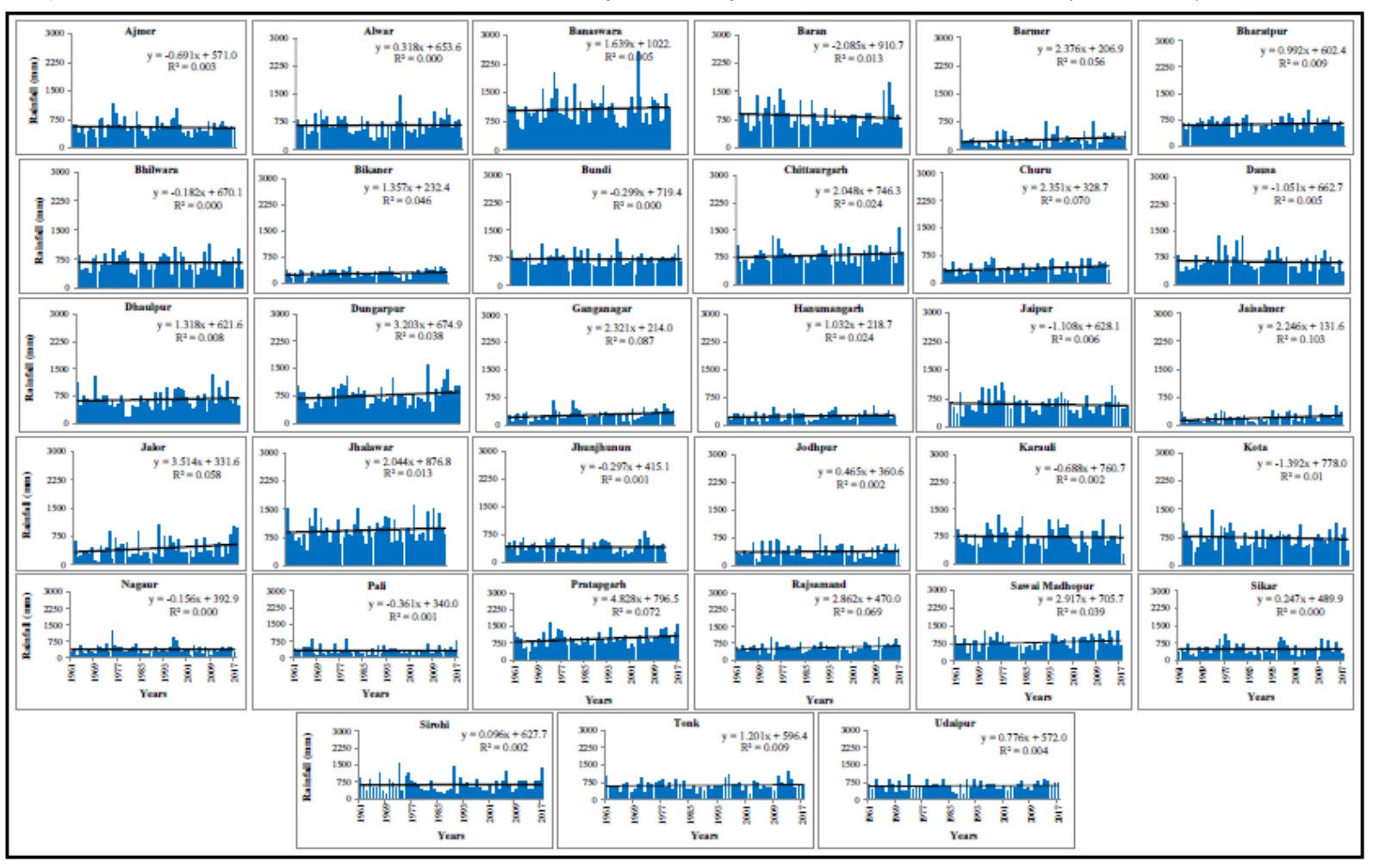

Figure 3

Station-wise mean annual rainfall over dryland ecosystem of north western India (1961-2017). 


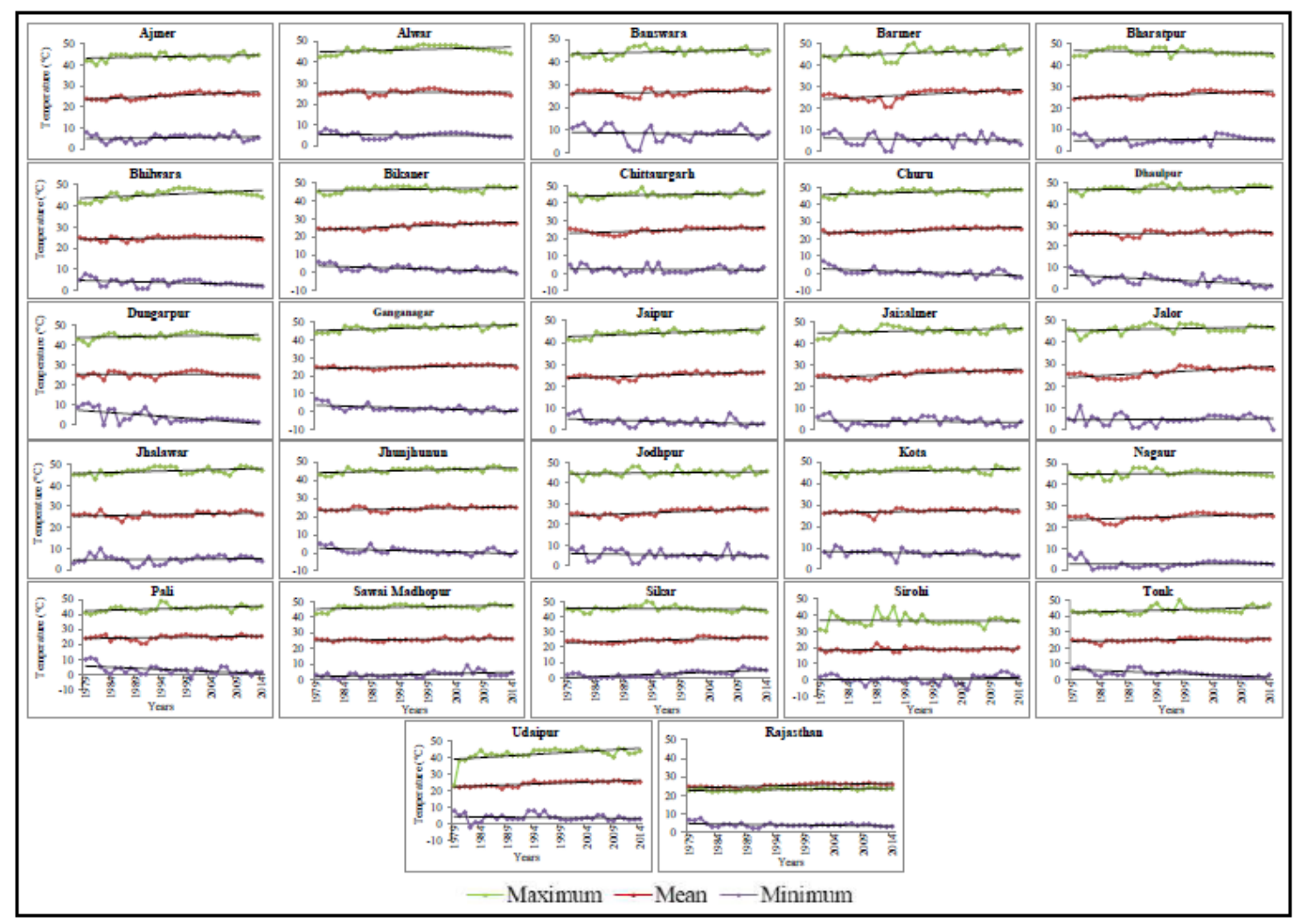

\section{Figure 4}

Station-wise annual mean, maximum and minimum temperature over dryland ecosystem of north western India (1979-2014).
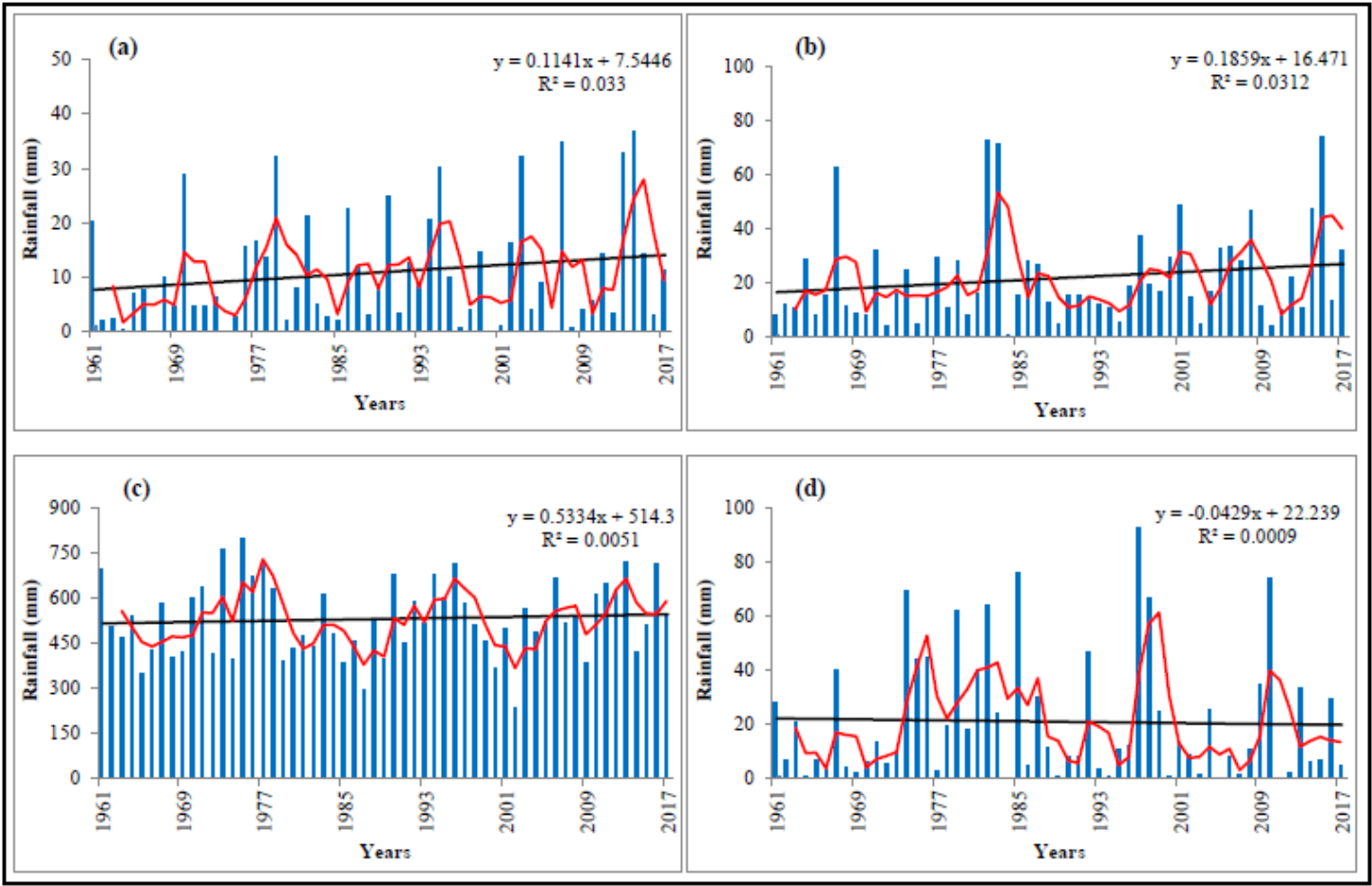

Figure 5

Year-wise seasonal rainfall over dryland ecosystem of north western India (1961-2017). (a) Winter season, (b) Pre-Monsoon season, (c) Monsoon season and (d) Post-Monsoon season. 


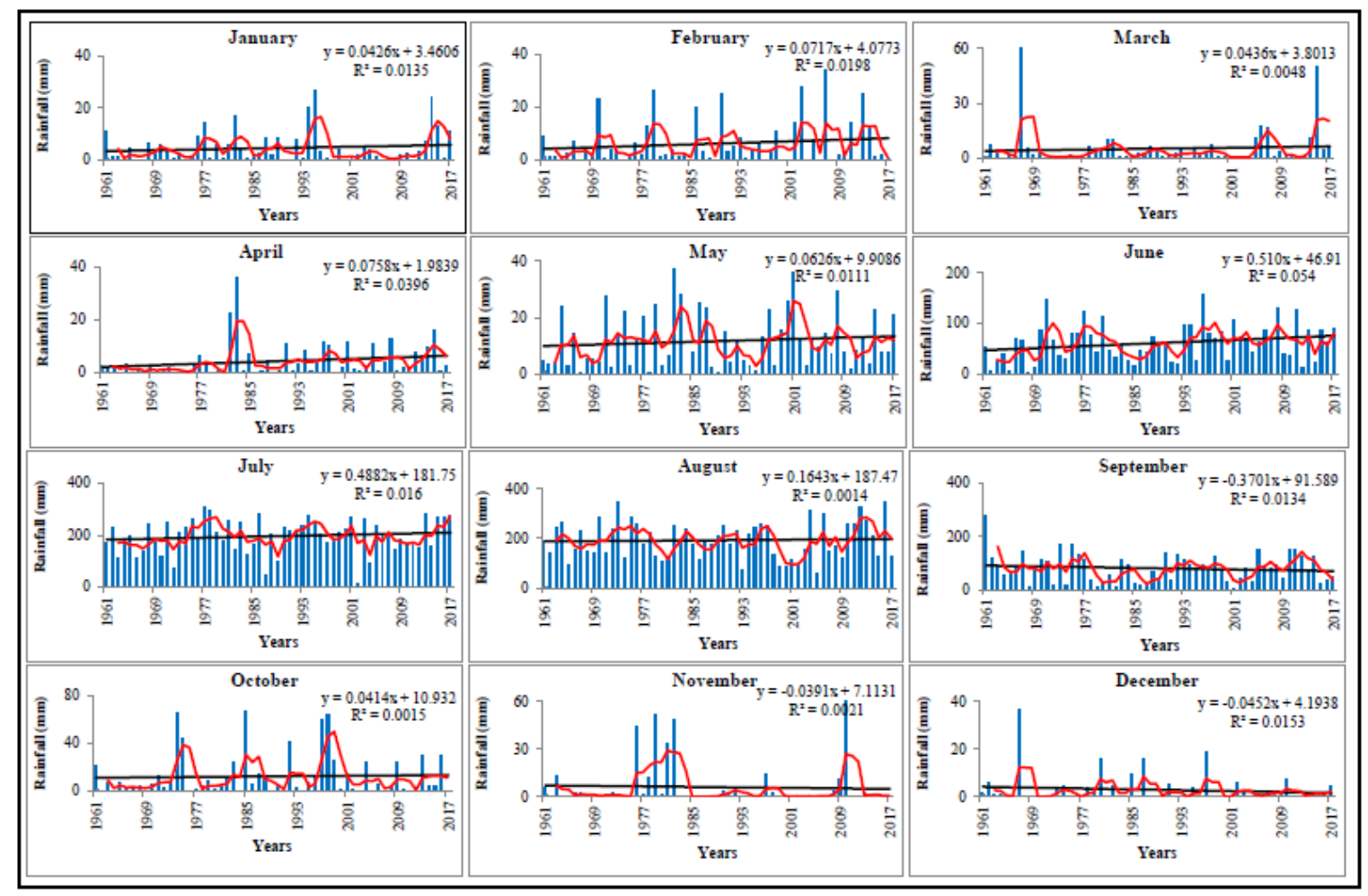

Figure 6

Year-wise monthly rainfall overdryland ecosystem of north western India (1961-2017).

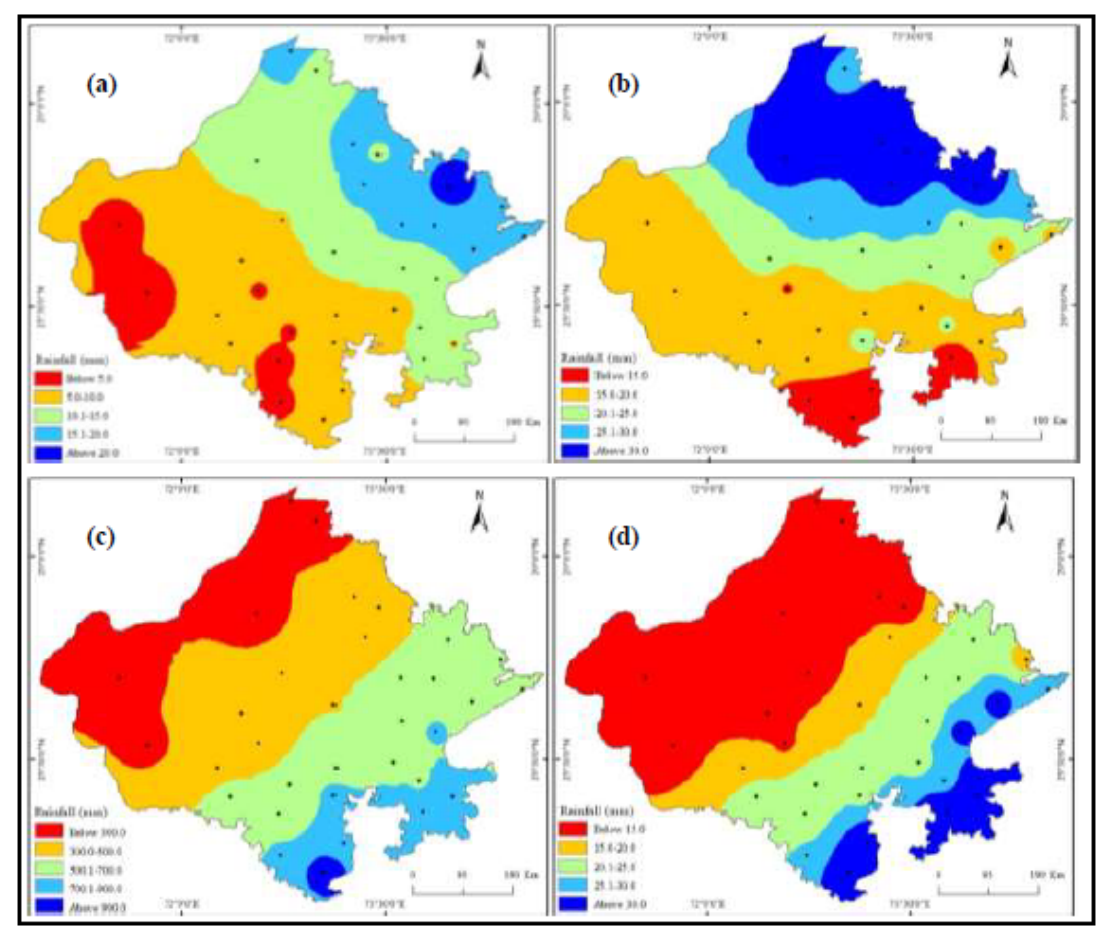

Figure 8

Spatial distribution of seasonalrainfall over dryland ecosystem of north western India (1961-2017). (a) Winter season, (b) Pre-Monsoon season, (c) Monsoon season and (d) Post-Monsoon season 


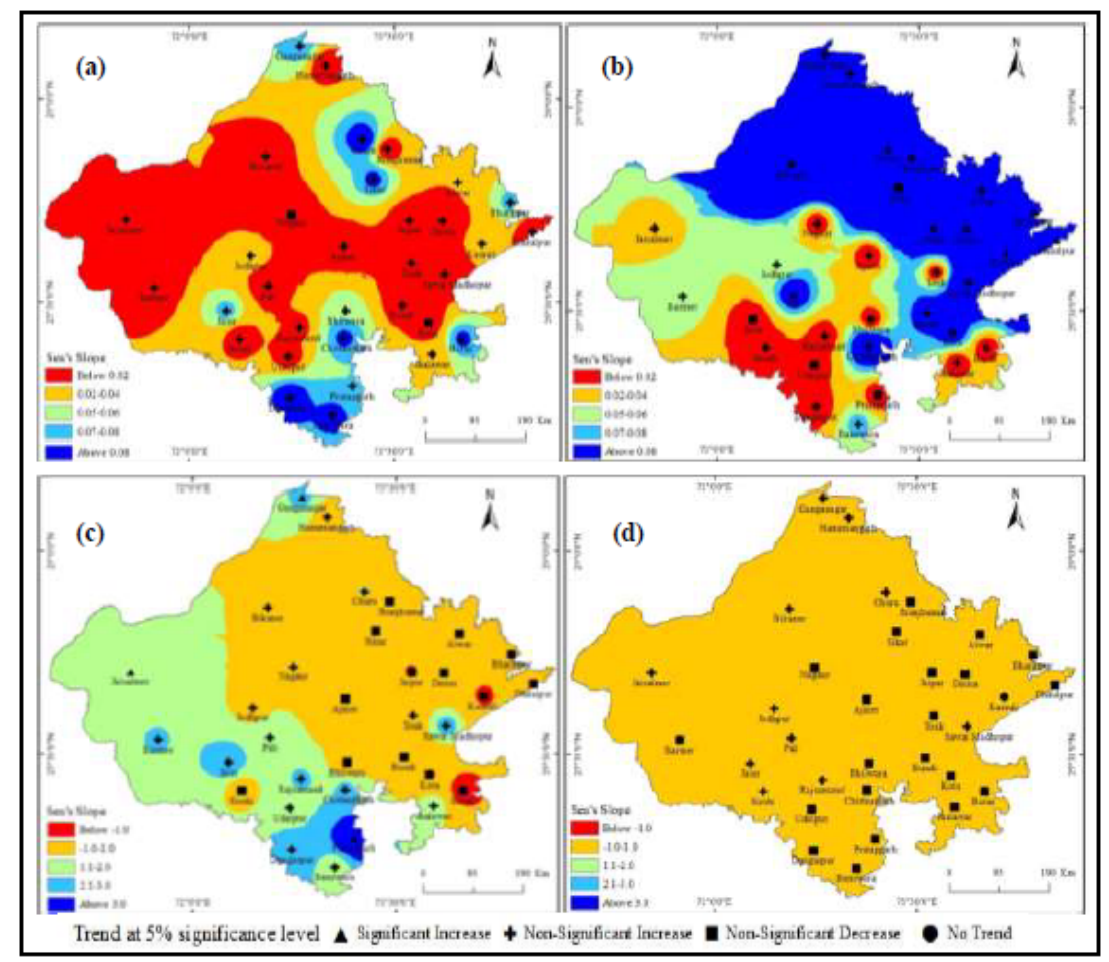

Figure 9

Spatial distribution of rainfall trends over dryland ecosystem of north western India (1961-2017) (a) Winter season, (b) Pre-Monsoon season, (c) Monsoon season and (d) Post-Monsoon season

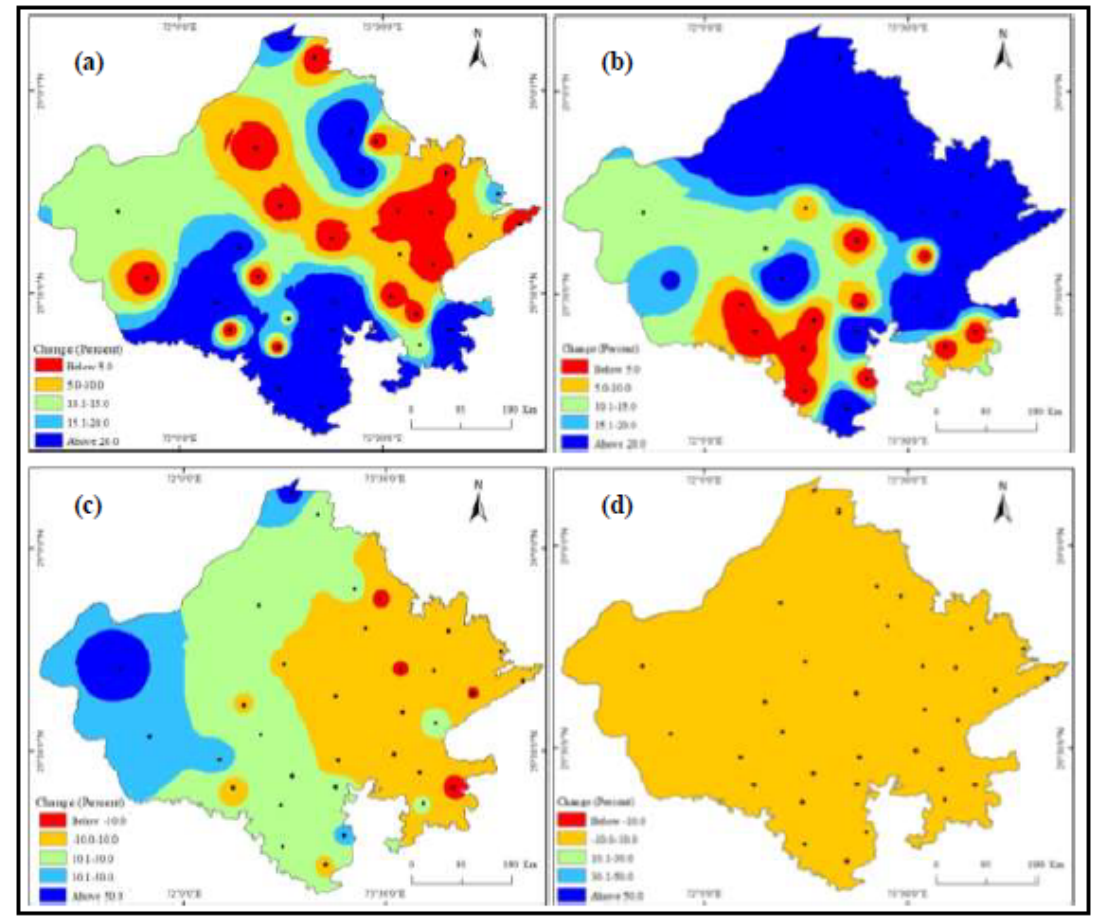

Figure 10

Spatial distribution of percent change in rainfall over dryland ecosystem of north western India (1961-2017). (a) Winter season, (b) Pre-Monsoon season, (c) Monsoon season and (d) Post-Monsoon season 


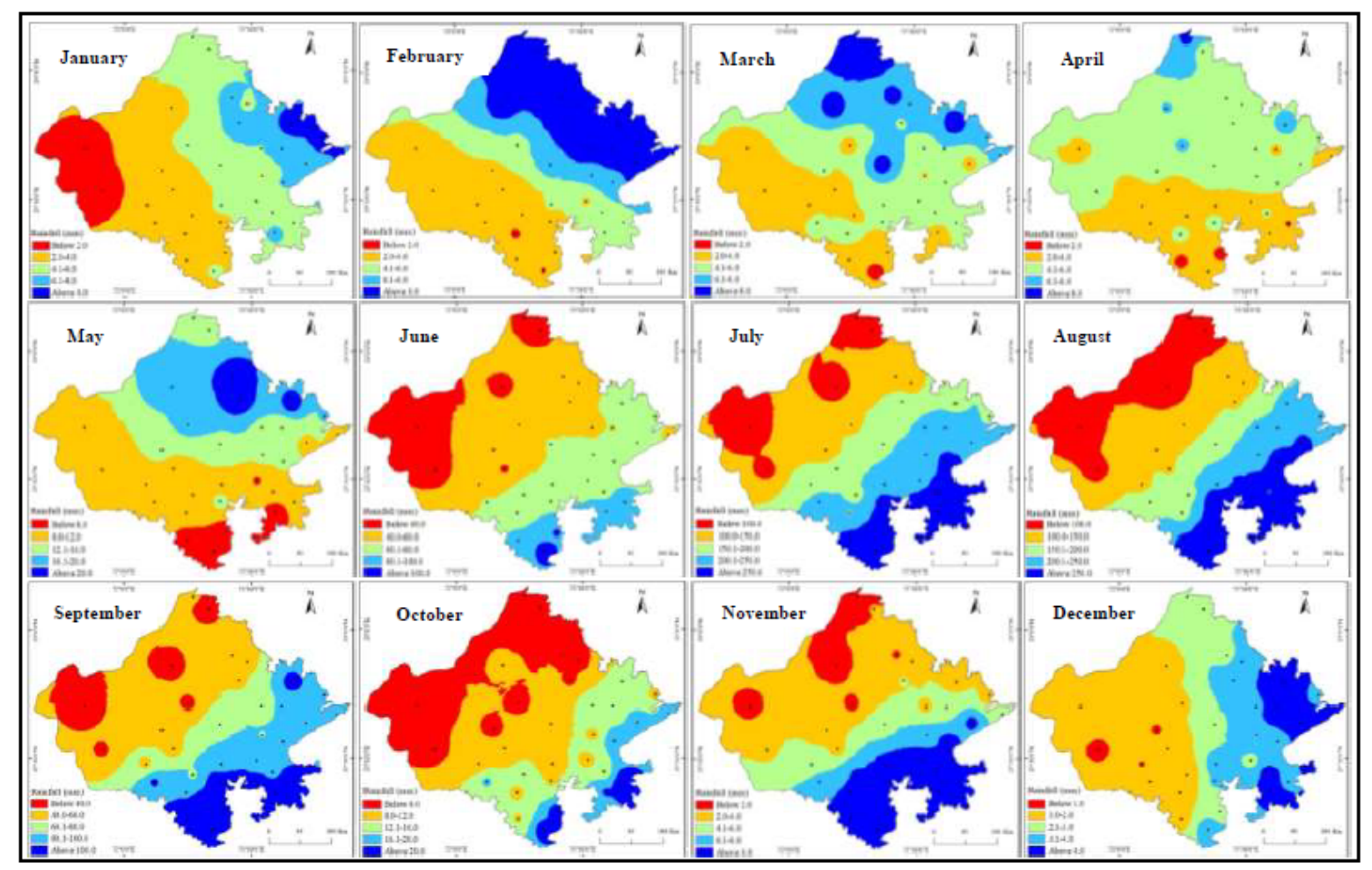

Figure 11

Spatial distribution of monthly rainfall over dryland ecosystem of north western India (1961-2017).

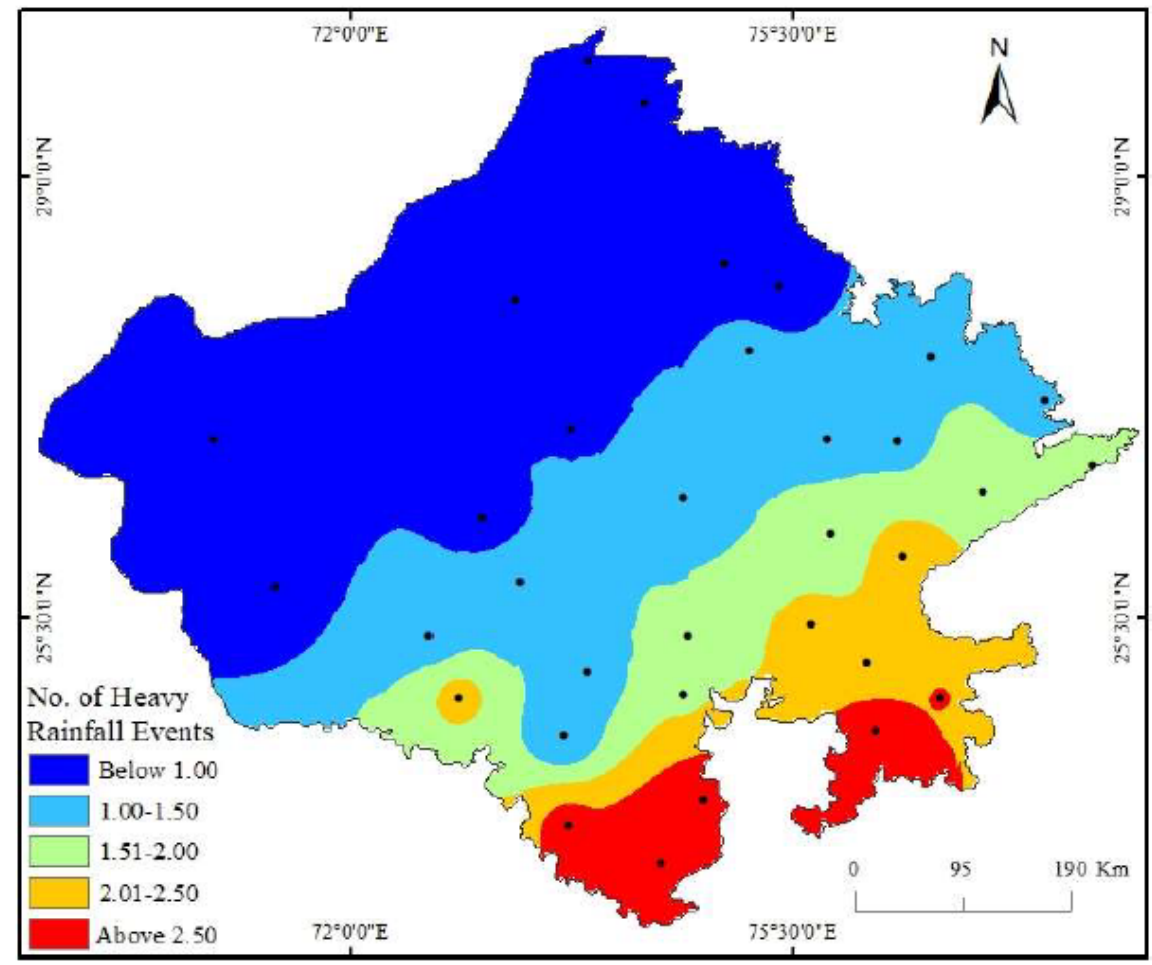

Figure 13

Spatial distribution of heavy rainfall events over dryland ecosystem of north western India (1961-2017). 